\title{
Utilizing Three Different Biochars for Attenuation of Toxic Acidic Mine Spoils Reflected by Lixiviate Quality Vis-a-Vis Phyto-Toxicity on Ocimum sanctum and Cassia angustifolia
}

Silphi Jain ${ }^{1}$, Vineet Yadav ${ }^{1}$, Dish Mishra ${ }^{1}$ Birendra Kumar², Yogita Deshmukh ${ }^{1}$, Nidhi Nigam ${ }^{1}$ and Puja Khare ${ }^{1, *}$

${ }^{1}$ Agronomy \& Soil Science Division, ${ }^{2}$ Plant Breeding Department, Central Institute of Medicinal and Aromatic Plants, P.O.-CIMAP, Near Kukrail Picnic Spot, Lucknow- 226 015, India.

\section{ARTICLE INFO}

\section{Article Type: Research Article}

Keywords:

Biochar

Mine spoil

Germination

Ocimum sanctum

Cassia angustifolia

Timeline:

Received: June 06, 2021

Accepted: August 02, 2021

Published: August 24, 2021

Citation: Jain S, Yadav V, Mishra D, Kumar B, Deshmukh Y, Nigam N, Khare P. Mine Spoils Reflected by Lixiviate Quality Vis-a-Vis Phyto-Toxicity on Ocimum sanctum and Cassia angustifolia. Glob J Agric Innov Res Dev. 2021; 8: 49-65.

DOl: https://doi.org/10.15377/2409-9813.2021.08.4

\begin{abstract}
Acidic mine rejects of pyretic sulphur coal mines were treated with biochar prepared from different feedstocks (distilled waste of Cymbopogon flexuosus (lemongrass) and Cymbopogon winterianus (Citronella) and the bark of Eucalyptus citriodora. The quality of lixiviate collected at three intervals $(0,15$, and 30 days) from each treated and untreated mine waste was examined, and holy basil (Ocimum sanctum) and East Indian senna (Cassia angustifolia) bioassays were carried out. Results indicate that all three biochars improve the lixiviate quality, i.e., Enhanced the $\mathrm{pH}$ of lixiviate up to 3 units and reduces phytotoxicity. However, their magnitude of impact on lixiviates quality and phytotoxicity was different. The biochar prepared from the distilled waste of Cymbopogon flexuosus showed more promising results. The neutralizing capacity and dissolved organic carbon content were the significant factors for the discrimination of the amendments. The tolerance of $O$. sanctum and C. angustifolia was significantly different from each other for a particular treatment.
\end{abstract}

\footnotetext{
*Corresponding Author

E-mail: kharepuja@rediffmail.com

Tel..+91 8004923033
}

(c) 2021 Jain et al. Published by Avanti Publishers. This is an open access article licensed under the terms of the Creative Commons Attribution NonCommercial License which permits unrestricted, non-commercial use, distribution and reproduction in any medium, provided the work is properly cited. (http://creativecommons.org/licenses/by-nc/4.0/) 


\section{Introduction}

Coal mining activities have a significant negative impact on the environment, particularly on aquatic resources. Sulfide minerals, mainly pyrite and marcasite, present in coal and mine rejects are largely responsible for acid mine drainage (AMD) formation due to aqueous weathering [1]. The acidic mine spoils (mine rejects and overburdens) have high sulphur compounds and are strongly acidic in nature [2] which ultimately leads to metal leaching and phytotoxic effects on vegetation [3]. The areas affected by acidic mine spoils are characterized by scarcity of vegetation due to high acidity and metal content with low fertility. Revegetation in the acidic mine spoil affected area is the answer to this problem. However, the major limitations of the re-vegetation of these areas are the high acidic, compact texture of spoils and the presence of the toxic element.

Biochar recently has attracted tremendous research interest for the remediation of metal contaminated mine soils [4-6]. The capacities [7], liming properties, reduce fertilizer needs due to reducing of nutrient leaching loss [8], reducing $\mathrm{N}_{2} \mathrm{O}$ emission from soil [9], diminishing disease incidence in crops [10], enhanced the availability of Ca, $\mathrm{Mg}$, and $\mathrm{Zn} \mathrm{[11]} \mathrm{and} \mathrm{reduction} \mathrm{in} \mathrm{the} \mathrm{bioavailability} \mathrm{of} \mathrm{toxic} \mathrm{metals} \mathrm{[12].} \mathrm{Biochars} \mathrm{have} \mathrm{a} \mathrm{highly} \mathrm{porous} \mathrm{structure,}$ contain various functional groups inserted, and have been shown to be effective in the adsorption of heavy metals (HMs), especially in aquatic systems $[13,14]$. Due to its sorption characteristics, biochar can reduce mobility and phytotoxicity of certain organic (e.g. Phenols, polychlorinated biphenyls, trihalomethanes, pesticides and halogenated hydrocarbons) and inorganic pollutants in the soil and, therefore, able to eliminate the limitations of phytoremediation [15]. The availability of alkaline elements such as $\mathrm{Ca}, \mathrm{K}$, and $\mathrm{Mg}$ in the biochar can also neutralize the acid produced due to aqueous weathering of sulphide minerals as well as decreasing the exchangeable ions of aluminum and hydrogen by adsorption $[16,17]$. Hence, biochar is considered as an HMs adsorbent as well as a promising agent for remediation of HMs polluted soil. It can play an important role to sequestration for HMs and neutralization of acidity of these spoils. Our recent studies on kinetic leaching of these mine rejects suggests that the biochar can be used to reduce the rate of acid production and alters the salt and carbon dissolution processes of mine rejects [18]. The acceleration in the alkali releasing rate was also observed after biochar addition.

The effectiveness of particular biochar for any application depends on its inherent propensities. Biochar with high recalcitrance could be used for carbon sequestration, while one with high alkaline elements acts as a good liming agent. Those with high cation exchange capacity (CEC), available nutrients, and high water holding capacity (WHC) could be better used as soil amendments to improve fertility. Feedstock with a different composition such as elemental composition; moisture content; and lignin, cellulose, and hemicellulose content affect the properties of the respective biochars after pyrolysis [19-21]. Biochars of the feedstock with the same category might show similar properties compared to those made from parent material of very different types. To optimize the benefits offered by biochar are to be maximized, it is important to develop an understanding of its physicochemical properties and their relations to functions in contaminated soil for a different range of biochar types [22].

The aims of this study were pre-screening of three biochars to identify their potential for the re-vegetation in the acidic mine spoil in the context of 1. potential neutralization of acidity, 2. the potential for leaching of HMs and nutrients, and 3. potential to reduce the eco-toxicological effects. Hence, the biochar prepared from the distilled waste of Cymbopogon flexuosus (lemongrass), Cymbopogon winterianus (Citronella) and the bark of Eucalyptus citriodora were used for the study. These biochars were varied in their $\mathrm{pH}, \mathrm{WHC}, \mathrm{CEC}$, and bulk densities (BDs). The lixiviate water collected from mine rejects, and biochar amendments at the different intervals were evaluated for their physic-chemical properties. The phytotoxicity of the lixiviate was tested using seeds of Tulsi (Ocimum sanctum) and Sena (Cassia angustifolia). O. sanctum is an antioxidant herb, while Cassia angustifolia is a shrub for laxative use. These are the secondary agricultural crops and are industrially important for a significant source of income and could be a part of the strategy for land management in the future. 


\section{Experimental}

\subsection{Biochar Preparation}

Biochars were prepared from Cymbopogon flexuosus (lemongrass), Cymbopogon winterianus (Citronella), and the bark of Eucalyptus citriodora (lemon-scented gum). The biomass samples were sieved for particle size of $0.211 \mathrm{~mm}$ and pyrolyzed in a programmed temperature fixed bed reactor (capacity: $300 \mathrm{~g} \pm 60$; tube diameter: $50 \mathrm{~mm}$; sample bed: up to $300 \mathrm{~mm}$ ) at $450{ }^{\circ} \mathrm{C}$ with a heating rate of $10{ }^{\circ} \mathrm{C}$ under inert conditions. Biochar physicochemical properties were determined through proximate, ultimate, and functional group chemistry analyses. Proximate analysis was done by ASTM method D3172. RSD [5] for replicates of moisture, volatile matter, and ash content were 0.36, 0.17, and 0.03, respectively. Total carbon, hydrogen, nitrogen, and sulphur were determined by Elemental Analyzer (Euro EA 3000 by Euro Vector)

\subsection{Sample Collection and Preparation}

Mine rejects (MRs) samples were collected from the coalfields of Jaintia Hills (Latitude: $25 \circ 100$ to $25 \circ 280 \mathrm{~N}$; Longitude: 92.080 and 92.340E), Meghalaya, India. MR samples were obtained from the coal quality control laboratory, North East Institute of Science and Technology (NEIST), Jorhat, Assam. Samples were collected at the selected mine from a lateral and vertical representation of overburden materials. The composite samples of MR were obtained from the target seam of the mine area. The samples were ground to a mesh size of 72 BS $(0.211$ $\mathrm{mm})$, preserved in desiccators, and used in all subsequent analyses.

Mine rejects were mixed with the biochar ( $40 \mathrm{~g}$ of biochar was added in $300 \mathrm{~g}$ of MR). The leaching experiments of pure MRs and MRs plus biochar were set as reported and optimized by [18]. All the experiments were performed in triplicates. The lixiviate water was collected separately from each experiment at different time points (0hr, 15 days, and 30 days). At each time, $400 \mathrm{~mL}$ of deionized water was added and allowed to stand for a minute to saturate the sample column. The lixiviate collected were characterized and used for germination study following the protocol described by [23]. For statistical comparisons, the samples were divided into four groups based on lixiviate water from MR [treatments: T1 (0 days), T2 (15 days) and T3 (30 days)], MR + biochar from $C$. flexuosus, $\mathrm{B}_{\mathrm{L}}$ [treatments: T4 (0 days), T5 (15 days) and T6 (30 days)], MR + biochar from E. citriodora, $\mathrm{B}_{\mathrm{E}}$ [treatments: T7 (0 days), T8 (15 days) and T9 (30 days)] and MR + biochar from $C$. winterianus, $\mathrm{B}_{\mathrm{c}}$ [treatments: T10 (0 days), T11 (15 days) and T12 (30 days)]. Statistical differences were confirmed by a two-sample t-test $(p=0.05)$ and by two-way repeated-measures ANOVA $(p=0.05)$ on transformations of the raw data.

\subsection{Seed Germination, Root and Shoot Elongation}

The incubation of seeds on filter paper soaked with lixiviate water was the method chosen due to the lower counter-effect of ions to particle interaction. The seeds of Holy basil (Ocimum sanctum), East Indian senna (Cassia angustifolia) were assayed for germination mine rejects lixiviate with and without biochar. The effect of lixiviate water was studied on 20 seeds of each plant. The imbibitions of seeds were carried out by immersing them into $20 \mathrm{~mL}$ lixiviate in plant growth cabinets in the dark at $25^{\circ} \mathrm{C}$ for $4 \mathrm{~h}$, the swelling period. Swollen seeds were then sown on Petri dishes with a double layer of filter paper (Whatman 1) wetted with $9 \mathrm{~mL}$ of solution in which seeds were immersed. The covers of the Petri dishes were closed and were kept at $25^{\circ} \mathrm{C}$ in the dark in growth cabinets for 5 days, determining the germination rate (GR) for every $24 \mathrm{~h}$. A 1-mm radicle emergence from seeds was considered seed germination. The root and shoot lengths of germinated seeds were measured only at 5 days of incubation. Our preliminary studies (unpublished) showed that this duration was required to determine the inhibitory effects of metals used. Each test was carried out in triplicate. The control group seeds were also treated the same way, using double distilled water (resistivity 18.0 M $\Omega$ ) instead of lixiviates water. Inhibition percentage, germination energy (GR), and germination period were calculated using the formula cited by Czabator's index [24]

The seed germination energy $(\mathrm{GE}, \%)=$ (number of germinating seeds/number of total seeds per treatment after germination for two days) $\times 100$ was calculated according to the method described by Hu et al. [25]. Germination index (GI) was calculated following the method reported by Wang et al.[26]. 


\subsection{Chemical and Metal Analyses}

Carbon $(\mathrm{C})$, hydrogen $(\mathrm{H})$, and nitrogen $(\mathrm{N})$ contents of the biochars were determined using a CHN Elemental Analyzer (Euro-Vector). Metals analysis ( $\mathrm{Ca}, \mathrm{Co}, \mathrm{Cr}, \mathrm{Cu}, \mathrm{Fe}, \mathrm{K}, \mathrm{Mg}, \mathrm{Ni}, \mathrm{Pb}$, and $\mathrm{Zn}$ ) of lixiviate water and germinated seeds of Sena (metal accumulation) was done by inductively coupled plasma (ICP-OES, Perkin Elmer, Optima 5300 V) following the standard protocol (APHA, 2005). $\mathrm{pH}$ (biochar:water:: 1:2.5 ratio), Eh (biochar: water ratio::1:5), and total dissolved solids (TDS) of the lixiviate solutions at different time intervals were done by Mettler SevenGo DuoTMpH/Conductivity meter SG23. Sulfate ion concentrations were determined by standard gravimetric analysis. The forms of $S$ in mine spoils were estimated by standard wet chemical methods [27].

\subsection{Chemical and Metal Analyses}

Carbon $(\mathrm{C})$, hydrogen $(\mathrm{H})$, and nitrogen $(\mathrm{N})$ contents of the biochars were determined using a CHN Elemental Analyzer (Euro-Vector). Metals analysis ( $\mathrm{Ca}, \mathrm{Co}, \mathrm{Cr}, \mathrm{Cu}, \mathrm{Fe}, \mathrm{K}, \mathrm{Mg}, \mathrm{Ni}, \mathrm{Pb}$, and $\mathrm{Zn}$ ) of lixiviate water and germinated seeds of Sena (metal accumulation) was done by inductively coupled plasma (ICP-OES, Perkin Elmer, Optima 5300 V) following the standard protocol (APHA, 2005). $\mathrm{pH}$ (biochar:water:: 1:2.5 ratio), Eh (biochar: water ratio::1:5), and total dissolved solids (TDS) of the lixiviate solutions at different time intervals were done by Mettler SevenGo DuoTMpH/Conductivity meter SG23. Sulfate ion concentrations were determined by standard gravimetric analysis. The forms of $\mathrm{S}$ in mine spoils were estimated by standard wet chemical methods [27].

\subsection{Chemometric Analysis}

Chemometric techniques provide a combination of mathematical and statistical methods for handling and interpreting chemical data effectively. Correlation and Principal component analysis (PCA) and corresponding analysis are the methods frequently used for multivariate data analysis. In the present study, to assess the lixiviate quality and phytotoxicity, many factors such as MRs, biochar amendments, leaching time, neutralization, pH, toxic elements, micro, and macronutrients and two plant species were involved. Hence, correlation, principal component (PCA), and corresponding analyses were applied using IBM SPSS Statistics 21.0 software. The major goal of PCA is dimension reduction; it combines numerous variables involved in the seed germination process into a single or a few variables. Constant variables or highly correlating variables cause no problems for PCA [28]. For the determination of the effect of lixiviate water composition after three types of biochar amendments on seed germination of Holy basil ( $O$. sanctum) and Sena ( $C$. angustifolia), PCA was applied to the data. Corresponding analysis was used to assess the similarity/ dissimilarity between the different treatments on the basis of input parameters. All the data were subjected to ANOVA, and differences between means were determined using Tukey's test. Values in the text preceded by " \pm " indicate standard error (SE).

\section{Results and Discussion}

\subsection{Physico-Chemical Characteristics of Biochars and Mine Reject (MR)}

Biochars from the distilled waste of $C$. flexuosus $\left(B_{L}\right), C$. winterianus $\left(B_{C}\right)$, and $E$. citriodora $\left(B_{E}\right)$ were prepared and characterized (Table 1$)$. The examined biochars from the distilled waste of grasses $\left(B_{\llcorner}\right.$and $\left.B_{C}\right)$ had lower total and organic carbon contents as compared to biochar from E. citriodora $\left(\mathrm{B}_{\mathrm{E}}\right)$. These findings are similar to as reported by Zhao et al. [29] and opposite to that reported by Wang et al. [30], where wood-derived biochar had lower total carbon content. The organic carbon content was quite higher than reported for biochar prepared from Jatropha carcus [33]. The available phosphorus content in $\mathrm{B}_{\mathrm{L}}$ was higher as compared to $\mathrm{BC}_{\mathrm{E}}$ and $\mathrm{B}_{\mathrm{C}}$. All biochars exhibit ash content $>10 \%$. The biochars from grasses $\left(B_{L}\right.$ and $\left.B_{C}\right)$ have much higher ash content than $B_{E}$. This could be due to different inorganic elements of the original biomass as well as impurities and typically contains diverse species of carbonates, phosphates, silicates, and sulfates, as suggested by [31]. Wang et al. [30] also reported the lower ash content in wood-derived biochar as compared to straw residue due to low mineral content in the wood. No sulphur is detected in the biochar. All biochars were alkaline; the $\mathrm{B}_{\mathrm{c}}(7.62 \pm 0.2)$ biochar had a lower $\mathrm{pH}$ as compared to $B_{L}(10.5 \pm 0.5)$ and $B C_{E}(9.2 \pm 0.6)$. Nanda et al. [32] reported that higher alkaline $\mathrm{pH}$ of prepared biochar due to its formation at elevated temperatures, which helps intensify the concentration of alkali metals, thus 
raising the biochar $\mathrm{pH}$ above 10. The $C E C$ values of $B_{E}, B_{L}$, and $B_{C}$ were $59.9 \pm 0.54$ meq kg-1, $159 \pm 1.61 \mathrm{meq} \mathrm{kg}^{-1}$, and $125 \pm 1.4 \mathrm{meq} \mathrm{kg}^{-1}$, respectively. Beside the low variations in the $\mathrm{pH}$, the differences in the $\mathrm{CEC}$ values among the biochar were high. This may be explained by the fact that CEC is related to cations (e.g., $\mathrm{K}, \mathrm{Ca}, \mathrm{Mg}$ ) present in biochar, which vary greatly with feedstock. A similar observation was also reported by Zhao et al. [29] with high variability in CEC values of biochar prepared from 12 waste biomasses ( 32.1 to $562 \mathrm{cmol} / \mathrm{kg}$ ). The WHCs of prepared biochar materials were 50,40 , and $50 \%$ for $B_{E}, B_{L}$, and $B_{C}$, respectively. The water holding capacities of this biochar were similar to those reported for biochar prepared from coir peat (69\%) and pine bark (45\%) (Kaudal et al. 2016). However, WHC values of biochar understudies were lower than the biochar prepared from Jatropha carcus [33]. The bulk densities of these biochar materials were $0.29 \pm 0.002 \mathrm{~g} \mathrm{~cm}^{-3}$ for $B_{E}, 0.45 \pm 0.001 \mathrm{~g} \mathrm{~cm}^{-3}$ for $B_{L}$, and $0.50 \pm 0.002 \mathrm{~g} \mathrm{~cm}^{-3}$ for $\mathrm{B}_{\mathrm{c}}$. The bulk densities of these biochar were within the ranges as reported for biochar prepared from pine bark (0.31 $\mathrm{g} \mathrm{cm}-3)$ [34], rice husk $\left(0.27-0.37 \mathrm{~g} \mathrm{~cm}^{-3}\right)$ and maize cob $\left(0.29-0.36 \mathrm{~g} \mathrm{~cm}^{-3}\right)$ [35]. All the prepared biochars have a high amount of $\mathrm{Fe}, \mathrm{Mg}, \mathrm{Ni}, \mathrm{Mn}, \mathrm{Ca}$ and $\mathrm{Zn}$ while $\mathrm{Pb}, \mathrm{Cr}, \mathrm{Cu}$ and Co were not detected.

Table 1: Physico-chemical properties of biochars ( $B C_{L}$ : biochar from C. flexuosus; $B C_{C}$ : biochar from C. winterianus and $B C_{E}$ : biochar from E. citriodora), mine rejects (MR) (Different letters within rows indicate significant differences at $p<0.05$ )

\begin{tabular}{|c|c|c|c|c|c|}
\hline Parameters & Unit & MR & $B C_{L}$ & $\mathrm{BC}_{\mathrm{c}}$ & $\mathrm{BC}_{\mathrm{E}}$ \\
\hline Ash & $\%$ & $59.6+0.4$ & $22 \pm 1.0$ & $19 \pm 0.9$ & $12 \pm 0.6$ \\
\hline VM & $\%$ & - & $29 \pm 0.8$ & $27 \pm 0.5$ & $33 \pm 0.9$ \\
\hline M & $\%$ & - & $3 \pm 0.2$ & $5 \pm 0.1$ & $5 \pm 0.2$ \\
\hline $\mathrm{C}$ & $\%$ & $29 \pm 0.9$ & $51 \pm 1.1$ & $59 \pm 1.2$ & $76 \pm 1.4$ \\
\hline $\mathrm{H}$ & $\%$ & $3.6 \pm 0.1$ & $3.6 \pm 0.1$ & $4 \pm 0.1$ & $8 \pm 0.4$ \\
\hline $\mathrm{N}$ & $\%$ & $1.2 \pm 0.1$ & $1.2 \pm 0.1$ & $1.8 \pm 0.1$ & $1.4 \pm 0.1$ \\
\hline $\mathrm{S}$ & $\%$ & $3.3 \pm 0.7$ & $N^{*}$ & ND & ND \\
\hline Organic carbon & $\%$ & - & $10 \pm 1.1$ & $15 \pm 1.4$ & $18 \pm 1.7$ \\
\hline Total phosphorus & $\mathrm{mg} \mathrm{kg}^{-1}$ & $122 \pm 18$ & $5520 \pm 123$ & $2530 \pm 167$ & $694 \pm 46$ \\
\hline Available phosphorus & $\mathrm{mg} \mathrm{kg}^{-1}$ & - & $58 \pm 2.1$ & $23 \pm 1.7$ & $21 \pm 1.6$ \\
\hline Ammoniacal nitrogen & $\mathrm{mg} \mathrm{kg}^{-1}$ & - & $99 \pm 9$ & $108 \pm 12$ & $78 \pm 5$ \\
\hline $\mathrm{pH}$ & & $3.7 \pm 0.5$ & $10.1 \pm 0.9$ & $8.2 \pm 0.2$ & $9.2 \pm 0.6$ \\
\hline CEC & meq $\mathrm{kg}^{-1}$ & - & $159 \pm 1.61$ & $125 \pm 1.4$ & $59.9 \pm 1.54$ \\
\hline $\mathrm{Ca}$ & $\mathrm{mg} \mathrm{kg}^{-1}$ & $122 \pm 11$ & $52 \pm 7$ & $52 \pm 4$ & $68 \pm 5$ \\
\hline Co & $\mathrm{mg} \mathrm{kg}^{-1}$ & $6.9 \pm 0.6$ & ND & ND & ND \\
\hline $\mathrm{Cr}$ & $\mathrm{mg} \mathrm{kg}^{-1}$ & $7.3 \pm 0.5$ & ND & ND & ND \\
\hline $\mathrm{Cu}$ & $\mathrm{mg} \mathrm{kg}^{-1}$ & $11.7 \pm 0.6$ & ND & ND & ND \\
\hline $\mathrm{Fe}$ & $\mathrm{mg} \mathrm{kg}^{-1}$ & $17 \pm 0.3$ & $3.7 \pm 0.8$ & $1.4 \pm 0.3$ & $1.2 \pm 0.5$ \\
\hline $\mathrm{Mg}$ & $\mathrm{mg} \mathrm{kg}^{-1}$ & $130 \pm 13$ & $824 \pm 29$ & $818 \pm 32$ & $433 \pm 45$ \\
\hline $\mathrm{Mn}$ & $\mathrm{mg} \mathrm{kg}^{-1}$ & $83 \pm 4$ & $80 \pm 3$ & $56 \pm 2$ & $66 \pm 3$ \\
\hline $\mathrm{Ni}$ & $\mathrm{mg} \mathrm{kg}^{-1}$ & $30 \pm 1.6$ & $6 \pm 0.6$ & $5.5 \pm 0.2$ & $6 \pm 0.3$ \\
\hline $\mathrm{Pb}$ & $\mathrm{mg} \mathrm{kg}^{-1}$ & 7. $5 \pm 0.4$ & ND & ND & ND \\
\hline $\mathrm{Zn}$ & $\mathrm{mg} \mathrm{kg}^{-1}$ & $8.2 \pm 0.5$ & $21 \pm 1.4$ & $58 \pm 1.6$ & $68 \pm 1.6$ \\
\hline
\end{tabular}

${ }^{*} \mathrm{ND}$ : Not detected.

The notable feature of MR was high sulphur content (3.3\% sulphate) with high ash (59.6\%) and carbon (29\%) contents. A similar finding had been documented by [36] when a total of 18 coal cleaning reject samples from four 
regions (Lauro Müller, Treviso, Urusanga and Criciúma) in Santa Clara State and Brazil were analysed. It has a highly acidic $\mathrm{pH}$ (3.7). The concentrations of $\mathrm{Ca}, \mathrm{Fe}, \mathrm{Cu}$, and $\mathrm{Mn}$ were higher in $\mathrm{MR}$ as compared to biochar, while $\mathrm{Mg}$ and $\mathrm{Zn}$ concentrations were higher in biochar as compared to MR.

\subsection{Lixiviate Quality}

The MR sample was subjected to leaching for different periods with and without the addition of biochar. Compositional parameters and the quality of lixiviates were determined over three different time periods $(0,15$, and 30 days) (Table 2). The $\mathrm{pH}$ values over different leaching time periods indicate that the lixiviates were highly acidic, showing an increase from 3.7 to 4.5 up to 15 days and then decreased to 4.1 after 30 days. The addition of biochar in MR promotes an increase in $\mathrm{pH}$ of the water; it exceeds the $\mathrm{pH}$ of lixiviate up to 2 to 3 units.

Table 2: Physico-chemical characteristic of lixiviate of different treatments (values are mean of three replications $\pm S E$ ) (Different letters within rows indicate significant differences at $p<0.05$ )

\begin{tabular}{|c|c|c|c|c|c|c|c|c|c|c|c|c|}
\hline \multirow{2}{*}{ Variables } & \multicolumn{12}{|c|}{ Treatments $^{*}$} \\
\hline & T1 & T2 & T3 & T4 & T5 & T6 & $\mathrm{T7}$ & $T 8$ & T9 & T10 & T11 & T12 \\
\hline $\mathrm{pH}$ & $3.7 \pm 0.3$ & $4.5 \pm 0.5$ & $4.1 \pm 0.3$ & $7.3 \pm 0.3$ & $6.9 \pm 0.5$ & $6.6 \pm 0.4$ & $5.3 \pm 0.2$ & $6.5 \pm 0.4$ & $6.8 \pm 0.3$ & $5.6 \pm 0.2$ & $6.2 \pm 0.1$ & $6.5 \pm 0.5$ \\
\hline$E_{h}(m V)$ & $194 \pm 17.6$ & $148 \pm 14.3$ & $174 \pm 14.7$ & $102 \pm 13.7$ & $12 \pm 1.6$ & $27 \pm 2.5$ & $211 \pm 13.6$ & $140 \pm 11.2$ & $127 \pm 12.9$ & $198 \pm 9.7$ & $136 \pm 12.1$ & $105 \pm 8.2$ \\
\hline TDS $\left(\mathrm{mg} \mathrm{L}^{-1}\right)$ & $799 \pm 54.8$ & $88 \pm 32.1$ & $67 \pm 24.1$ & $3470 \pm 364$ & $546 \pm 54$ & $200 \pm 42$ & $2310 \pm 231$ & $97 \pm 51$ & $80 \pm 24$ & $2950 \pm 504$ & $99 \pm 43$ & $81 \pm 11$ \\
\hline Ca $\left(\mathrm{mg} \mathrm{g}^{-1}\right)$ & $103 \pm 13$ & $23 \pm 4$ & $32 \pm 5$ & $430 \pm 14$ & $44 \pm 8.5$ & $46 \pm 2.3$ & $364 \pm 12$ & $13.5 \pm 10$ & $18.7 \pm 6.1$ & $312 \pm 19$ & $5.5 \pm 0.3$ & $5.9 \pm 0.4$ \\
\hline Co $\left(\mathrm{mg} \mathrm{g}^{-1}\right)$ & $1.49 \pm 0.4$ & $0.22 \pm 0.02$ & $0.08 \pm 0.01$ & $0.19 \pm 0.1$ & $0.07 \pm 0.01$ & $0.04 \pm 0.01$ & $0.33 \pm 0.06$ & $0.02 \pm 0.01$ & $0.08 \pm 0.01$ & $0.28 \pm 0.05$ & $0.03 \pm 0.01$ & $0.06 \pm 0.02$ \\
\hline $\mathrm{Cr}\left(\mathrm{mg} \mathrm{g}^{-1}\right)$ & $2.2 \pm 0.7$ & $1.1 \pm 0.6$ & $0.6 \pm 0.08$ & $1.0 \pm 0.05$ & $0.5 \pm 0.02$ & $0.17 \pm 0.8$ & $0.41 \pm 0.02$ & $0.46 \pm 0.03$ & $0.48 \pm 0.02$ & $0.37 \pm 0.03$ & $0.60 \pm 0.03$ & $0.34 \pm 0.01$ \\
\hline $\mathrm{Cu}\left(\mathrm{mg} \mathrm{g}^{-1}\right)$ & $3.3 \pm 1.2$ & $0.2 \pm 0.4$ & $0.3 \pm 0.7$ & $0.3 \pm 1.2$ & $0.1 \pm 0.9$ & $0.2 \pm 0.6$ & $0.64 \pm 0.05$ & $0.35 \pm 0.06$ & $0.19 \pm 0.04$ & $0.29 \pm 0.03$ & $0.15 \pm 0.02$ & $0.10 \pm 0.02$ \\
\hline $\mathrm{Fe}\left(\mathrm{mg} \mathrm{g}^{-1}\right)$ & $2085 \pm 136$ & $16 \pm 4.8$ & $20 \pm 2.9$ & $12 \pm 2.1$ & $12 \pm 3.2$ & $83 \pm 5.5$ & $13 \pm 2.5$ & $53 \pm 3.1$ & $40 \pm 2.8$ & $10 \pm 1.1$ & $30 \pm 1.6$ & $11 \pm 0.9$ \\
\hline $\mathbf{K}\left(\mathrm{mg} \mathrm{g}^{-1}\right)$ & $19 \pm 3.8$ & $24 \pm 3.8$ & $23 \pm 2.7$ & $1295 \pm 145$ & $216 \pm 13$ & $102 \pm 12$ & $1194 \pm 134$ & $216 \pm 41$ & $190 \pm 6$ & $1171 \pm 161$ & $270 \pm 25$ & $210 \pm 14$ \\
\hline $\mathbf{M g}\left(\mathrm{mg} \mathrm{g}^{-1}\right)$ & $54 \pm 4.8$ & $6 \pm 3.7$ & $6 \pm 0.5$ & $270 \pm 23$ & $19 \pm 3.2$ & $13 \pm 0.8$ & $115 \pm 19$ & $13 \pm 2$ & $11 \pm 2$ & $123 \pm 16$ & $24 \pm 1$ & $14 \pm 2$ \\
\hline $\mathbf{N i}\left(\mathrm{mg} \mathrm{g}^{-1}\right)$ & $1.7 \pm 0.8$ & $0.6 \pm .02$ & $1.2 \pm 0.8$ & $0.5 \pm .01$ & $0.4 \pm .12$ & $0.6 \pm .15$ & $1.1 \pm .02$ & $0.1 \pm .01$ & $0.08 \pm .01$ & $0.69 \pm .01$ & $0.1 \pm .01$ & $0.2 \pm .01$ \\
\hline $\mathbf{P b}\left(\mathrm{mg} \mathrm{g}^{-1}\right)$ & $0.36 \pm 0.1$ & $0.39 \pm .14$ & $0.41 \pm .14$ & $0.28 \pm .05$ & $0.27 \pm .06$ & $0.28 \pm .08$ & $0.31 \pm .05$ & $0.29 \pm .07$ & $0.28 \pm .01$ & $0.26 \pm .05$ & $0.18 \pm .05$ & $0.18 \pm .01$ \\
\hline $\mathrm{Zn}\left(\mathrm{mg} \mathrm{g}^{-1}\right)$ & $16.0 \pm 3.5$ & $1.0 \pm .44$ & $1.9 \pm .24$ & $1.2 \pm .09$ & $1.0 \pm .06$ & $1.3 \pm .04$ & $1.9 \pm .07$ & $0.66 \pm .01$ & $1.8 \pm 037$ & $1.21 \pm .02$ & $0.76 \pm .02$ & $1.11 \pm .03$ \\
\hline Sulphate (\%) & $0.30 \pm .03$ & $0.043 \pm .02$ & $0.031 \pm .01$ & $1.36 \pm 0.06$ & $0.18 \pm 0.02$ & $0.029 \pm .01$ & $0.76 \pm 0.06$ & $0.14 \pm 0.03$ & $0.15 \pm 0.01$ & $0.98 \pm 0.01$ & $0.19 \pm 0.01$ & $0.16 \pm 0.01$ \\
\hline Nitrate $\left(\mathrm{mg} \mathrm{g}^{-1}\right)$ & $47 \pm 9.5$ & $46.7 \pm 8.8$ & $34.2 \pm 4.4$ & $80.2 \pm 20.1$ & $68.5 \pm 11.1$ & $69.6 \pm 10.1$ & $69 \pm 11$ & $64 \pm 4.1$ & $56 \pm 2.1$ & $74.59 \pm 14.1$ & $67.16 \pm 7.2$ & $66.65 \pm 4.2$ \\
\hline DOC (\%) & $18.1 \pm 2.8$ & $0.1 \pm 0.98$ & $9.1 \pm 1.7$ & $11.3 \pm 4.5$ & $19.5 \pm 4.8$ & $12.1 \pm 3.2$ & $21.4 \pm 2.2$ & $24.3 \pm 2.3$ & $15.3 \pm 1.2$ & $18.7 \pm 2.1$ & $28.6 \pm 2.4$ & $14.3 \pm 2.0$ \\
\hline
\end{tabular}

*lixiviate water from MR [treatments: T1 (0 day), T2 (15 days) and T3 (30 days)], MR + biochar from C.flexuosus, BL [treatments: T4 (0 day), T5 (15 days) and T6(30 days)], MR + biochar from E. citriodora, $\mathrm{B}_{\mathrm{E}}$ [treatments: $\mathrm{T7}$ (0 day), T8(15 days) and T9 (30 days)] and MR + biochar from C. winterianu, $\mathrm{BC}$ [treatments: $\mathrm{T} 10(0$ day), $\mathrm{T} 11$ (15 days) and T12 (30 days)].

Iron and alkaline elements $(\mathrm{K}, \mathrm{Ca}$, and $\mathrm{Mg}$ ) are the dominating elements present in the MR lixiviate water. Martín et al. [37] reported that Fe and alkaline elements in MR are related to feldspar, oxyhydroxides, and hydrated sulfates (jarosite) of ferric iron, which is formed as the result of the oxidation of MR. The soluble micronutrients $(\mathrm{Co}, \mathrm{Cu}, \mathrm{Ni}, \mathrm{Zn})$ and toxic elements $(\mathrm{Cr}$ and $\mathrm{Pb})$ were detected in the lixiviate water from $\mathrm{MR}$ and were higher in the initial flush (T1) (Table 2). Among micro-nutrients, Zn concentration was more prevalent (1-16 $\left.\mu \mathrm{gmL}^{-1}\right)$ followed by $\left(0.3\right.$ to3.3 $\left.\mu \mathrm{gmL}^{-1}\right)$, Ni $\left(0.6\right.$ to $1.7 \mu \mathrm{gmL}^{-1}$ ) and Co (Not detectable, ND to $1.4 \mu \mathrm{gmL}^{-1}$ ). Among toxic elements, $\mathrm{Cr}$ (0.6 to $2.2 \mu \mathrm{gmL}^{-1}$ ) was more prevalent, followed by $\mathrm{Pb}\left(0.36\right.$ to $\left.0.4 \mu \mathrm{gmL}^{-1}\right)$. This pattern of leaching elements was similar to their concentration levels. This could be explained by MR-water interaction processes which firstly break down metal sulfides, then adsorb metals by the iron oxyhydroxide colloids and organic matter as suggested by [38]. $\mathrm{Pb}$ concentration was found to increase with the increment in the $\mathrm{pH}$, while $\mathrm{Cr}$ concentration showed an opposite trend with $\mathrm{pH}$. Lixiviate of biochar treatments had significant $(\mathrm{p}<0.05)$ reduced the concentration of $\mathrm{Fe}$, alkaline elements ( $\mathrm{K}, \mathrm{Ca}$ and $\mathrm{Mg}$ ), soluble micro-nutrients ( $\mathrm{Co}, \mathrm{Ni}$, and $\mathrm{Zn}$ ), and toxic elements 
$(\mathrm{Cr}, \mathrm{Cu}$, and $\mathrm{Pb})$ as compared to that of pure mine reject $\left(\mathrm{T}_{1}, \mathrm{~T}_{2}\right.$, and $\left.\mathrm{T}_{3}\right)$. Also, the micro-nutrients and toxic element concentrations in lixiviate water of three biochar amendments were significantly different from each other $(p=0.05)$. At zero days, sulphate and nitrate concentrations in biochar amendments $(\mathrm{T} 4, \mathrm{~T} 7$, and $\mathrm{T} 10)$ were higher than mine rejects (T1). However, the reverse is true after 15 and 30 days. Similar data have been obtained in coal residues of abandoned mines of Santa Catarina state in Brazil [39]. Dissolved organic carbon (DOC) showed no trend with the time and biochar amendments. $\Sigma$ DOC in 30 days was significantly $(p<0.05)$ higher in the biochar amendments as compared to MR. Moreno-Barriga et al. (2017) concluded that biochars increased recalcitrant soil $C$ to reclaim tailings mine residue at the Mining District of Cartagena-La Unión (SE Spain).

Results indicate that the lixiviate of MR was highly acidic, and biochar addition enhanced the $\mathrm{pH}$ towards the neutral. This confirms that biochar is an effective amendment for $\mathrm{pH}$ neutralization of $\mathrm{MR}$, also observed by [40]. Furthermore, [41] reported that carbonate dissolution appears to be a key mechanism for acid neutralization in $\mathrm{MR}$. The $\mathrm{pH}$ of MR lixiviate increases with the leaching time, though it remains acidic. The increase in $\mathrm{pH}$ of lixiviate of mine reject with leaching time was due to in situ neutralization. The presence of alkaline earth metals, nutrients, and toxic metals in the lixiviate of mine reject was due to the dissolution of minerals such as quartz, kaolinite, calcite, illite, sphalerite, and pyrite [1]. The possible reasons for this may be the dissolution of hosted minerals, solubility, and dilution effect. The solubility of some metals is strongly dependent on the $\mathrm{pH}$ dependents and decreased sharply with $\mathrm{pH}>6$ [42]. This can be evidenced for $\mathrm{Fe}, \mathrm{Mg}, \mathrm{Ni}, \mathrm{Co}, \mathrm{Cu}$, and $\mathrm{Pb}$, which negatively correlate with $\mathrm{pH}$.

Dissolve organic carbon (DOC) content in lixiviate has a vital contribution to the solubility of metal and other ions. The negative correlation between $\mathrm{pH}$ and $\mathrm{DOC}$ suggests that dissolved organic content in lixiviate is enhanced with an increase in its acidity. The acidic $\mathrm{pH}$ leads to the release of low molecular weight compounds from the coal fines present in the mine rejects. These compounds, in turn, formed soluble complexes with metals present in the mine rejects. They enhanced their dissolution by preventing the absorption of the solid phase. This theory could be applied for $\mathrm{Fe}, \mathrm{Mg}$, and $\mathrm{Co}$ as they showed a positive correlation with DOC. However, Ca, K, Zn, Cu, and $\mathrm{Pb}$ showing a negative correlation with DOC suggests that these elements formed stable complexes with organic matter, which adsorbed on solid phase and as an increase in the $\mathrm{pH}$ further reduced their solubility.

The positive correlation of $\mathrm{Fe}$ and $\mathrm{SO}_{4}{ }^{2-}$ with each other and with $\mathrm{Co}, \mathrm{Ni}$, and $\mathrm{Cr}$ suggests the dissolution of their sulphides associated with pyrites minerals. In biochar amendments, the enhancement of the $\mathrm{pH}$ is consistent with the alkali nature of the biochar (Table 1). Dissolution oxides, hydroxides, and carbonates (e.g., ash) of base cation $(\mathrm{Ca}, \mathrm{Mg}, \mathrm{K}$ and $\mathrm{Na}$ ) present in the biochar act as a liming agent when applied to acidic mine soil [43]. However, the neutralization pattern in the lixiviate water collected in the biochar amendments was different. The $B_{L}$ amendment showed a prevalent increase from an initial $\mathrm{pH}$ of 3.7 to 7.3 (at day 0 ), whereas $\mathrm{B}_{\mathrm{C}}$ and $\mathrm{B}_{\mathrm{E}}$ amended mine reject showed an increase in $\mathrm{pH}$ to a lesser extent (from3.7 to 5.6 and 5.3, respectively). The high $\mathrm{pH}$ and $\mathrm{CEC}$ of $B_{L}$ could be the possible reason for its highest buffering capacity. However, the buffering capacity of $B_{C}$ and $B_{E}$ were similar despite the differences in their $\mathrm{pH}$. This suggests that different phenomena are occurring during the leaching of different biochar amendments. Besides the $\mathrm{pH}$, the $\mathrm{CEC}$ and organic carbon content of biochar could also be responsible for the release of the buffering elements such as $\mathrm{Ca}$ and $\mathrm{Mg}$.

The correlation pattern of $\mathrm{DOC}$ and $\mathrm{SO}_{4}{ }^{2-}$ with each other and alkaline metal was different in amendment of three different biochar. This demonstrates the difference in dissolution mechanism among the biochar treatments. In the biochar $B_{L}$ and $B_{C}$, the $\mathrm{pH}$ increased due to more dissolution of neutralizing elements such as $\mathrm{Ca}, \mathrm{K}$, and $\mathrm{Mg}$ which are capable of buffering the acid produced. It was supported by the positive correlation of $\mathrm{pH}$ with the $\mathrm{Ca}, \mathrm{K}, \mathrm{Mg}$, and $\mathrm{SO}_{4}{ }^{2-}$. While in $\mathrm{B}_{\mathrm{E}}$ amendment, an increase in $\mathrm{pH}$ was due to lower production of acid and the neutralization elements. The negative correlation of $\mathrm{pH}$ with the $\mathrm{Ca}, \mathrm{K}, \mathrm{Mg}$, and $\mathrm{SO}_{4}{ }^{2-}$ support these phenomena.

The addition of biochar reduced the mineral and toxic metal content in lixiviate. The addition of biochar in the MR affects the concentration of individual elements in lixiviate water differently. The release pattern of mineral and toxic elements in the three biochar amendments was almost similar but had a significant $(p<0.05)$ difference in magnitude. In biochar amendments, $\mathrm{pH}$ and dissolved organic carbon are crucial factors since they can significantly impact the solubility and distribution of ions in the soil solution. The increase in $\mathrm{pH}$ reduces the 
solubility of metal complexes. It may also be possible that at higher $\mathrm{pH}$, precipitation of $\mathrm{Fe}$ and $\mathrm{Al}$ oxyhydroxide may also reduce the solubility of these metals. The decrease in the metal ion in biochar treatments may also be due to their sorption on the biochar surface. The adsorption of metal on particulate/biochar surface followed by the formation of stable complexes restricts their mobility in the lixiviates. On the other hand, metal-binding with DOC facilitates their release in the lixiviate [44]. Hence, this could be the reason for the variability in the mineral and toxic metal behavior in lixiviate. For example, the negative correlation of $\mathrm{Zn}$ with pH suggests that $\mathrm{Zn}$ concentration in lixiviate water was controlled by the dissolution-precipitation of oxide and hydroxide. This could also be the reason for the behavior of $C_{O}$ in lixiviate of $B_{L}$ and $B_{C}$ amendments. The positive correlation of $C_{0}$ with $\mathrm{pH}$ in $\mathrm{B}_{\mathrm{E}}$ suggests that $\mathrm{pH}$ facilitates its mobility. The positive correlation of $\mathrm{Pb}$ in all treatments and $\mathrm{Cu}$ in $\mathrm{B}_{\mathrm{E}}$ with DOC indicates they have an affinity to form the aqueous organo-metallic compounds and remain in the solution or absorbed in the particles. The electrostatic interaction and the precipitation on biochar surface might be the main $\mathrm{Pb}$ immobilization mechanism of biochar prepared at $500^{\circ} \mathrm{C}$. Oxygen-containing functional groups on biochar surfaces may also be formed complexes with cationic $\mathrm{Pb}$ to some extent [45]. The negative correlation of Cu with $D O C$ in $B_{L}$ and $B_{C}$ could be due to its distribution between the solid surface phase (adsorption) and the liquid solution.

Similarly, the correlations of $\mathrm{Ni}$ with $\mathrm{pH}$ and $\mathrm{DOC}$ were different in all treatments suggests the dominance of different processes in different treatments. Generally, Ni solubility decreases with increasing pH in inorganic systems due to the increased sorption of $\mathrm{Ni}(\mathrm{II})$ species on negatively charged mineral surfaces.

Also, Ni readily substitutes into the hematite present in the mine reject [46]. Hence, it is very unlikely that the Ni present in mine reject can be mobilized due to the presence of DOC in the solution.

\subsection{Phytotoxicity}

The seed germination could be considered a highly sensitive process during various stresses such as acidity and metal contamination, as in this period, seed coats become softer and more permeable to contaminants [47]. The present study indicates that $100 \%$ inhibitory effect of zero daylixiviate of mine reject (T1) on 0 . sanctum and $62.5 \%$ on C. angustifolia (Table 3). However, inhibition of seeds of both the plants was significantly $(p<0.05)$ lower in lixiviate collected at 15 and 30 days. Germination energy (GE), germination Index (GI), and germination rate (GR) of seeds were enhanced by increasing the time of lixiviate collection. Inhibition in Ocimum sanctum was highly reduced in T2 and T3 as compared to T1. The degree to which the lixiviate water quality inhibits germination differed with acidity, metal content, nutrient availability, and plant species. Results indicate that at high acidity ( $\mathrm{pH}: 3.7)$ and high Fe content, C. angustifolia appeared to be more tolerant as compared to O. sanctum. While at pH: 4.7 and lower Fe content, later one is more tolerant. Besides the highly acidic nature of mine reject lixiviate water, 0-75\% and $38-50 \%$ germination occurred in 0 . sanctum and C. angustifolia, respectively. Probably, acidic conditions accelerated germination due to deterioration of the seed coat, which leads to hydration. Also, the germination process is very tolerant to acidification. The retardation of the growth rate of seedlings in mine reject lixiviate as compared to control (DW) was more prevalent to the most acidic conditions with the heavy metal load. However, seedlings were grown in more acidic $(\mathrm{pH})$, and high heavy metals load were not healthy. They were yellowish in color due to the accumulation of high concentrations of iron hydroxide and sulphide. However, the seedling growth in MR lixiviates was improved gradually with the leaching time. This suggests that the metal tolerant capacity of these plants can improve in acidic mine sites with due course of time.

Biochar amendments reduced the inhibition of seed germination, which further decreases with the leaching time. This is attributed to the lower acidity, lower metal content, and higher nutrient availability. Among biochar amendments, inhibition is more in $B_{E}$ treatments for $C$. angustifolia. The inhibition in $O$. sanctum was similar between all biochar treatments. However, inhibition in seed germination is lower in lixiviate collected at 30 days as compared to 0 and 15 days. The improvement in the germination rate after biochar addition might be due to the decline in acidity and metal concentration. Also, the carbon compounds released from biochar could act as humiclike supermolecular compounds. They can deliver bioactive molecules by adhering to seedlings. This enhanced bioactivity masks off the negative effect of the metal and favor coleoptiles growth [48]. This is corroborated with the correlation of roots and shoots lengths of $O$. sanctum and C. angustifolia with DOC of the lixiviate. The other 
priming effect of biochar addition was due to the enhanced water-soluble nitrogen content and nutrients such as $\mathrm{P}$ and $\mathrm{K}$ [49]. The good correlation of root and shoot lengths with $\mathrm{Ca}, \mathrm{K}, \mathrm{Mg}$, and $\mathrm{P}$ in biochar treatments is validating this phenomenon. This is further supported by the strong negative correlation between the inhibition and potassium accumulation in the seedlings of C. angustifolia.

Table 3: Germination parameters of Sena and Holy basil grown in different leachate water (values are mean of three replications \pm SE)

\begin{tabular}{|c|c|c|c|c|c|c|c|c|}
\hline \multirow{3}{*}{ Treatments } & \multicolumn{4}{|c|}{ Sena } & \multicolumn{4}{|c|}{ Holy basil } \\
\hline & GE $\mathscr{Q}$ & GIs & GRss & Inhibition & GE & GI & GR & Inhibition \\
\hline & \multicolumn{8}{|c|}{$(\%)$} \\
\hline Control & 100 & $27.6 \pm 5.9$ & $3.68 \pm 1.5$ & $40 \pm 5.5$ & $60 \pm 8.6$ & $16.66 \pm 6.5$ & $4.46 \pm 1.5$ & $30 \pm 5.5$ \\
\hline $\mathrm{T} 1$ & - & $1.3 \pm 0.34$ & $1.05 \pm 0.18$ & $62 \pm 6.5$ & - & $1.13 \pm 0.5$ & $1.08 \pm 0.35$ & 100 \\
\hline $\mathrm{T} 2$ & $5 \pm 0.5$ & $3.4 \pm 1.3$ & $1.24 \pm 0.45$ & $56 \pm 7.8$ & $5 \pm 0.55$ & $2.37 \pm 1.5$ & $1.54 \pm 0.45$ & $20 \pm 6.0$ \\
\hline T3 & $20 \pm 5.5$ & $9.3 \pm 2.7$ & $1.58 \pm 0.34$ & $50 \pm 3.4$ & $20 \pm 5.0$ & $7.07 \pm 1.5$ & $2.92 \pm 0.95$ & $15 \pm 4.9$ \\
\hline $\mathrm{T} 4$ & $5 \pm 0.3$ & $10.5 \pm 3.2$ & $4.18 \pm 0.23$ & $36 \pm 1.4$ & $30 \pm 4.2$ & $10.20 \pm 3.5$ & $73.85 \pm 6.75$ & $30 \pm 3.6$ \\
\hline T5 & $10 \pm 1.5$ & $8.7 \pm 2.2$ & $2.79 \pm 0.32$ & $25 \pm 4.6$ & $35 \pm 4.8$ & $11.03 \pm 4.5$ & $3.77 \pm 1.45$ & $10 \pm 3.2$ \\
\hline T6 & $30 \pm 2.7$ & $15.5 \pm 5.5$ & $2.47 \pm 0.64$ & $19 \pm 3.6$ & $20 \pm 7.3$ & $7.40 \pm 3.5$ & $2.85 \pm 0.34$ & $15 \pm 7.3$ \\
\hline $\mathrm{T7}$ & $5 \pm 0.5$ & $1.43 \pm 0.08$ & $0.6 \pm 0.1$ & $41 \pm 3.1$ & $10 \pm 0.9$ & $3.33 \pm 0.3$ & $1.0 \pm 0.1$ & $29 \pm 2.1$ \\
\hline $\mathrm{T} 8$ & $20 \pm 2.5$ & $6.33 \pm 1.2$ & $2.0 \pm 0.4$ & $32 \pm 1.3$ & $25 \pm 1.1$ & $9.03 \pm 1.3$ & $3.2 \pm 0.1$ & $15 \pm 1.3$ \\
\hline T9 & $15 \pm 2.3$ & $4.97 \pm 0.9$ & $1.8 \pm 0.3$ & $29 \pm 1.5$ & $15 \pm 1.2$ & $6.03 \pm 1.1$ & $2.2 \pm 0.1$ & $11 \pm 0.8$ \\
\hline $\mathrm{T} 10$ & $5 \pm 0.4$ & $2.17 \pm 0.7$ & $1.0 \pm 0.1$ & $29 \pm 2.4$ & $15 \pm 1.0$ & $4.90 \pm 0.5$ & $1.4 \pm 0.1$ & $26 \pm 0.9$ \\
\hline $\mathrm{T} 11$ & $15 \pm 1.5$ & $6.03 \pm 1.6$ & $2.2 \pm 0.2$ & $21 \pm 1.1$ & $20 \pm 1.3$ & $6.20 \pm 0.7$ & $2.2 \pm 0.2$ & $13 \pm 0.3$ \\
\hline $\mathrm{T} 12$ & $15 \pm 0.6$ & $4.77 \pm 0.9$ & $1.6 \pm 0.1$ & $20 \pm 1.9$ & $20 \pm 1.4$ & $6.40 \pm 0.7$ & $2.4 \pm 0.2$ & $11 \pm 0.2$ \\
\hline
\end{tabular}

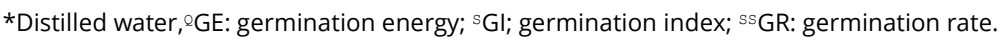

The variations in the shoot, root, and total elongation of seedlings (Figure 1) are the first visual effect of any stress on the plant. The lixiviate water of mine rejects enhanced the elongation in root and reduced the shoot length of seedlings of $O$. sanctum as compared to distilled water. It has no effect on the shoot length of $C$. angustifolia, but reduced the root length $C$. angustifolia as compared to distilled water. The addition of biochar in mine reject further enhanced the elongation in root and shoot of seedlings as compared to mine reject and control (distilled water). The elongation is more pronounced in the lixiviate water obtained from mine reject with $\mathrm{B}_{\mathrm{L}}(\mathrm{T} 4, \mathrm{~T} 5$, and $\mathrm{T} 6)$ for both the plants. The diverse effects of acidic lixiviate water on root and shoot elongation in both the plant are probably due to the different distribution of heavy metals, nutrients, and plant tolerance. The difference in inhibition in the root and shoot part of the plant resulted from a different distribution of heavy metals in plants. The elongation is more pronounced in the lixiviate water obtained from mine reject with $B_{L}$ (T4, $\mathrm{T} 5$, and T6) for both the plants. This could be attributed to high $\mathrm{pH}$ and high content of $\mathrm{Ca}, \mathrm{Mg} \mathrm{SO}_{4}{ }^{2-}$ and nitrate in its lixiviate.

\subsection{Metal Accumulation}

The metal and mineral content accumulated in the seedlings can be another measure to evaluate the plant tolerance in acidic mine environments and biochar amendments. The dry mass weight of germinated seeds of Ocimum was insufficient for the metal analysis; therefore, further studies on metal accumulation were done in only C. angustifolia (Table 4). Concentrations of $\mathrm{K}, \mathrm{Mg}$ and carbon in seedling of $\mathrm{C}$. angustifolia showed almost similar in all treatments. However, significant $(p<0.05)$ reduction was observed in the concentration of Ca $(117-69$ $\mu g g^{-1}$ to 50 to $\left.92 \mu \mathrm{gg}^{-1}\right)$ and Fe (1.93-5.15 $\mathrm{\mu gg}^{-1}$ to $\left.0.92-3.04 \mu \mathrm{gg}^{-1}\right)$ in seedling germinated in lixiviate of biochar amendments as compared to that of mine reject. Toxic elements such as $\mathrm{Co}, \mathrm{Cr}, \mathrm{Pb}, \mathrm{Ni}$, and $\mathrm{Zn}$ were significantly 
less $(p<0.05)$ accumulated in seedlings grown in lixiviate of biochar amendments (T4-T12) as compared to that of mine reject (T1-T3). $\mathrm{Cr}$ and $\mathrm{Pb}$ were found significantly $(\mathrm{p}<0.05)$ higher in seeds grown in $\mathrm{T} 1$. In the case of $\mathrm{Cu}$, no significant $(p<0.05)$ variation was observed in its accumulation in seedlings grown T1, T4, T7, and T11 (lixiviate water collected at zero days). However, the accumulation of Cu was higher in $\mathrm{T} 2$ and $\mathrm{T} 3$ as compared to respective biochar amendments (T5, T6, T8, T9, T11, and T12). The highest concentration of Fe and Zn was observed in T1.

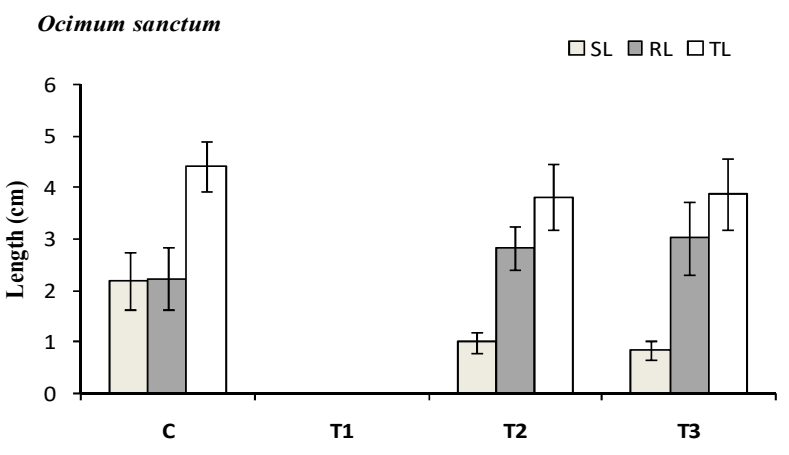

Cassia angustifolia
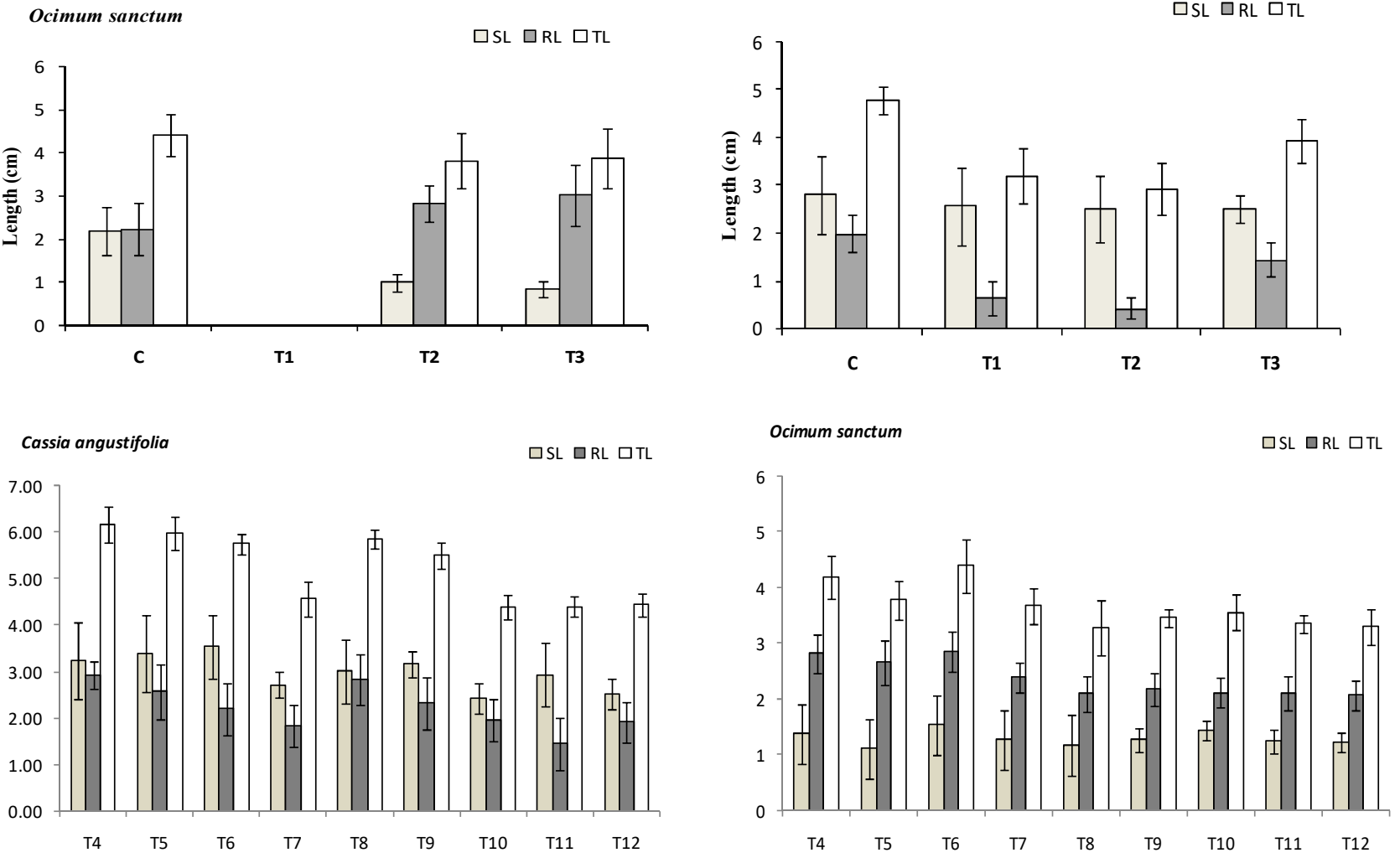

Figure 1: Root and shoot elongation of $O$. sanctum and C. angustifolia in different treatments (bars indicate mean of three replicates and the vertical bar indicates $\pm \mathrm{SE}$ ) [ ${ }^{*} \mathrm{SL}$ : Shoot length; RL: Root length and TL: SL+RL].

Table 4: Accumulation of different metals as well as carbon and hydrogen contents $\left(\mu \mathrm{g} \mathrm{g}^{-1}\right)$ in seedlings of Sena (values are mean of three replication \pm SE)

\begin{tabular}{|c|c|c|c|c|c|c|c|c|c|c|c|c|}
\hline & $\mathrm{Ca}$ & Co & $\mathrm{Cr}$ & $\mathrm{Cu}$ & $\mathrm{Fe}$ & $\mathbf{K}$ & Mg & $\mathbf{N i}$ & $\mathbf{P b}$ & $\mathrm{Zn}$ & C & H \\
\hline $\mathrm{T} 1$ & $68.7 \pm 2.1$ & $0.08 \pm 0.07$ & $1.26 \pm 0.2$ & $0.52 \pm 0.12$ & $5.15 \pm 0.98$ & $728.3 \pm 42.7$ & $11.96 \pm 3.7$ & $0.26 \pm 0.02$ & $0.32 \pm .01$ & $2.82 \pm 0.9$ & $42.8 \pm 4.9$ & $6.53 \pm 1.5$ \\
\hline $\mathrm{T} 2$ & $104.6 \pm 22 . .7$ & $0.06 \pm 0.03$ & $1.22 \pm 0.3$ & $0.82 \pm 0.02$ & $4.58 \pm 0.24$ & $847.5 \pm 54.7$ & $8.22 \pm 2.7$ & $0.22 \pm 0.01$ & $0.59 \pm 0.01$ & $7.81 \pm 1.8$ & $44.3 \pm 2.0$ & $6.58 \pm 1.3$ \\
\hline T3 & $117.6 \pm 25.1$ & $0.05 \pm 0.02$ & $0.92 \pm 0.12$ & $0.63 \pm 0.07$ & $1.93 \pm 0.32$ & $743.3 \pm 36.7$ & $12.88 \pm 5.7$ & $0.17 \pm 0.03$ & $0.33 \pm 0.04$ & $11.12 \pm 2.9$ & $50.0 \pm 3.9$ & $7.42 \pm 3.2$ \\
\hline T4 & $82.3 \pm 12.3$ & $0.04 \pm 0.02$ & $0.82 \pm 0.11$ & $0.53 \pm 0.03$ & $1.41 \pm 0.12$ & $864.8 \pm 42.7$ & $70.35 \pm 7.5$ & $0.15 \pm 0.01$ & $0.01 \pm 0.0$ & $1.96 \pm 0.6$ & $42.8 \pm 5.8$ & $6.53 \pm 0.8$ \\
\hline T5 & $45.3 \pm 24.4$ & $0.07 \pm 0.03$ & $0.55 \pm 0.11$ & $0.46 \pm 0.05$ & $0.94 \pm 0.77$ & $792.0 \pm 63.7$ & $13.72 \pm 3.6$ & $0.01 \pm 0.0$ & $0.14 \pm 0.02$ & $1.80 \pm 0.2$ & $44.2 \pm 3.9$ & $6.58 \pm 1.4$ \\
\hline T6 & $50.6 \pm 12.6$ & $0.07 \pm 0.02$ & $0.73 \pm 0.07$ & $0.48 \pm 0.02$ & $2.54 \pm 0.20$ & $787.1 \pm 63.7$ & $12.26 \pm 2.9$ & $0.10 \pm 0.01$ & $0.13 \pm 0.05$ & $1.93 \pm 0.3$ & $46.7 \pm 2.9$ & $7.10 \pm 2.0$ \\
\hline $\mathrm{T7}$ & $92.1 \pm 10.3$ & $0.09 \pm 0.01$ & $1.02 \pm 0.10$ & $0.43 \pm 0.03$ & $2.01 \pm 0.42$ & $894.8 \pm 35.1$ & $89.45 \pm 3.1$ & $0.16 \pm 0.01$ & $0.11 \pm 0.01$ & $2.19 \pm 0.8$ & $45.8 \pm 5.8$ & $6.03 \pm 1.1$ \\
\hline T8 & $65.1 \pm 14.1$ & $0.08 \pm 0.01$ & $0.85 \pm 0.13$ & $0.46 \pm 0.05$ & $1.54 \pm 0.62$ & $762.0 \pm 41.2$ & $21.44 \pm 4.6$ & $0.05 \pm 0.00$ & $0.19 \pm 0.01$ & $1.91 \pm 0.3$ & $47.2 \pm 3.9$ & $6.18 \pm 1.2$ \\
\hline T9 & $59.1 \pm 12.7$ & $0.08 \pm 0.02$ & $0.73 \pm 0.14$ & $0.41 \pm 0.02$ & $3.04 \pm 0.60$ & $757.1 \pm 43.2$ & $18.12 \pm 1.7$ & $0.11 \pm 0.01$ & $0.13 \pm 0.02$ & $1.90 \pm 0.2$ & $49.3 \pm 2.1$ & $6.28 \pm 2.1$ \\
\hline T10 & $84.3 \pm 13.7$ & $0.08 \pm 0.02$ & $0.86 \pm 0.12$ & $0.51 \pm 0.03$ & $1.68 \pm 0.19$ & $884.8 \pm 43.0$ & $74.35 \pm 8.5$ & $0.15 \pm 0.01$ & $0.01 \pm 0.01$ & $1.90 \pm 0.4$ & $43.8 \pm 2.1$ & $6.40 \pm 0.6$ \\
\hline T11 & $55.3 \pm 14.2$ & $0.07 \pm 0.01$ & $0.55 \pm 0.11$ & $0.47 \pm 0.05$ & $1.02 \pm 0.87$ & $751.0 \pm 31.2$ & $15.72 \pm 2.2$ & $0.03 \pm 0.01$ & $0.13 \pm 0.01$ & $1.88 \pm 0.1$ & $44.2 \pm 1.3$ & $6.52 \pm 1.2$ \\
\hline T12 & $50.6 \pm 12.7$ & $0.07 \pm 0.02$ & $0.63 \pm 0.07$ & $0.46 \pm 0.02$ & $2.68 \pm 0.31$ & $741.1 \pm 23.2$ & $13.56 \pm 1.9$ & $0.07 \pm 0.01$ & $0.13 \pm 0.02$ & $1.91 \pm 0.1$ & $49.1 \pm 1.4$ & $7.00 \pm 1.3$ \\
\hline
\end{tabular}


The correlation between metal accumulation and their impact on germination parameters gave a clear picture of phytotoxicity (Table 5). The inhibition of C. angustifolia was correlated with $\mathrm{Ca}(r=0.71)$, Ni $(r=0.86), \mathrm{Zn}(r=$ $0.61), \mathrm{Cr}(r=0.92), \mathrm{Cu}(r=0.63), \mathrm{Pb}(r=0.71)$ and $\mathrm{Fe}(r=0.66)$. Shoot length of $C$. angustifolia was correlated with $\mathrm{Ca}$ $(r=-0.61)$ while the root length was correlated with $\mathrm{Ni}(r=-0.65), \mathrm{Cr}(r=-0.64), \mathrm{Cu}(r=-0.63)$ and $\mathrm{Pb}(r=-0.76)$. The negative correlation of root length with $\mathrm{Ca}, \mathrm{Cr}, \mathrm{Cu}, \mathrm{Fe}, \mathrm{Ni}$, and $\mathrm{Zn}$ accumulated in the seed suggests that these elements were responsible for the reduction in the root. Shoot length had negatively correlated with $\mathrm{Cr}, \mathrm{Cu}, \mathrm{Fe}, \mathrm{Pb}$, and $\mathrm{Zn}$ indicating their inhibitory effect on its growth. The positive correlation of inhibition with $\mathrm{Cr}, \mathrm{Cu}, \mathrm{Fe}, \mathrm{Ni}, \mathrm{Pb}$, and $\mathrm{Zn}$ indicates that these elements are responsible for the reduction in germination. Lower accumulation was observed in the seedling grown in the biochar amendments. Metal accumulation pattern demonstrates that the biochar has the potential to reduce the metal bioavailability in the AMD-affected areas.

Table 5: Results of principal component analysis for lixiviate water and germination parameters

\begin{tabular}{|c|c|c|c|c|c|c|c|c|}
\hline & \multicolumn{2}{|c|}{ MR } & \multicolumn{2}{|c|}{$M R+B L$} & \multicolumn{2}{|c|}{$M E+B E$} & \multicolumn{2}{|c|}{$M R+B C$} \\
\hline & P1 & $\mathbf{P 2}$ & P1 & P2 & P1 & P2 & P1 & P2 \\
\hline $\mathrm{pH}$ & 0.803 & -0.595 & 0.998 & 0.002 & 0.950 & 0.050 & 0.382 & 0.618 \\
\hline TDS & -0.996 & 0.089 & 0.914 & 0.086 & 0.842 & 0.158 & 0.906 & 0.094 \\
\hline DOC & -0.840 & 0.542 & 0.117 & 0.883 & 0.142 & 0.858 & 0.249 & 0.751 \\
\hline SO4 & -0.997 & 0.075 & 0.918 & 0.082 & 0.826 & 0.174 & 0.921 & 0.079 \\
\hline $\mathrm{Fe}$ & -0.993 & 0.116 & 0.631 & 0.369 & 0.545 & 0.455 & 0.062 & 0.938 \\
\hline Ger(S) & 0.841 & 0.541 & 0.953 & 0.047 & 0.728 & 0.272 & 0.445 & 0.555 \\
\hline $\ln (s)$ & -0.917 & -0.398 & -0.998 & 0.002 & -0.970 & 0.030 & 0.954 & 0.046 \\
\hline Ger(O) & 0.771 & 0.637 & 0.860 & 0.140 & 0.399 & 0.601 & 0.984 & 0.016 \\
\hline $\ln (0)$ & -0.998 & 0.062 & -0.646 & 0.354 & -0.960 & 0.040 & 0.963 & 0.037 \\
\hline SL(S) & -0.993 & 0.114 & 0.994 & 0.006 & 0.996 & 0.004 & 0.121 & 0.879 \\
\hline $\mathrm{RL}(\mathrm{S})$ & 0.418 & 0.908 & 0.978 & 0.022 & 0.327 & 0.673 & 0.076 & 0.924 \\
\hline $\mathrm{SL}(\mathrm{O})$ & 0.965 & -0.261 & 0.065 & 0.935 & 0.012 & 0.988 & 0.926 & 0.074 \\
\hline $\mathrm{RL}(\mathrm{O})$ & 0.998 & -0.055 & 0.004 & 0.996 & 0.608 & 0.392 & 0.555 & 0.445 \\
\hline $\mathrm{Ca}$ & 0.989 & 0.145 & 0.746 & 0.254 & 0.941 & 0.059 & 0.965 & 0.035 \\
\hline $\mathrm{K}$ & 0.501 & -0.865 & 0.890 & 0.110 & 0.859 & 0.141 & 0.936 & 0.064 \\
\hline $\mathrm{Mg}$ & -0.220 & 0.975 & 0.867 & 0.133 & 0.866 & 0.134 & 0.920 & 0.080 \\
\hline Co & -0.976 & -0.218 & 0.852 & 0.148 & 0.837 & 0.163 & 0.903 & 0.097 \\
\hline $\mathrm{Ni}$ & -0.890 & -0.456 & 0.221 & 0.779 & 0.299 & 0.701 & 0.633 & 0.367 \\
\hline $\mathrm{Zn}$ & 0.957 & 0.289 & 0.091 & 0.909 & 0.859 & 0.141 & 0.016 & 0.984 \\
\hline $\mathrm{Cr}$ & -0.678 & -0.735 & 0.199 & 0.801 & 1.000 & 0.000 & 0.710 & 0.290 \\
\hline $\mathrm{Cu}$ & 0.704 & -0.711 & 0.609 & 0.391 & 0.088 & 0.912 & 0.984 & 0.016 \\
\hline $\mathrm{Pb}$ & 0.980 & -0.231 & 0.800 & 0.200 & 0.118 & 0.882 & 0.903 & 0.097 \\
\hline Variance (\%) & 61.000 & 31.000 & 68.000 & 29.000 & 60.000 & 32.000 & 65.000 & 30.000 \\
\hline
\end{tabular}

Significant clustering of the variable is shown in bold.

\subsection{Discrimination Among the Treatments Using Correspondence Analysis}

The associations among the treatments and the interactions among the lixiviate water parameters and seed germination parameters were examined using correspondence analysis. Figure (2a) shows the correspondence analysis of the entire data set (treatments, lixiviate water compositions, and germination parameters of all the 
treatments). We found that the $T_{1}$ was not associated with the other treatments. $T_{1}$ is associated with the Fe content present in the lixiviate water. $\mathrm{T}_{1}$ has a very low $\mathrm{pH}$, high Fe content, and high mortality in the seed. Also, it grouped with the germination of $O$. sanctum. The lixiviate water collected from biochar treatments at zero hours $\left(T_{4}, T_{7}\right.$, and $\left.T_{10}\right)$ was also segregated from other treatments and clustered with $\mathrm{Mg}_{1} \mathrm{SO}_{4}{ }^{2-}$ and $\mathrm{TDS}$ and germination rate of 0 . sanctum (Figure 2). The lixiviate collected at 15 and 30 days (T2, T3, T5, T6, T8, T9, T11, and T12) showed little distinction, clustering together on the plot along with the other physiochemical and germination parameters. Corresponding analysis showed a clear distinction among the initial lixiviate of MR, biochar type, and lixiviate collection time. The correspondence analysis clearly showed distinction of T1 from other treatments was probably
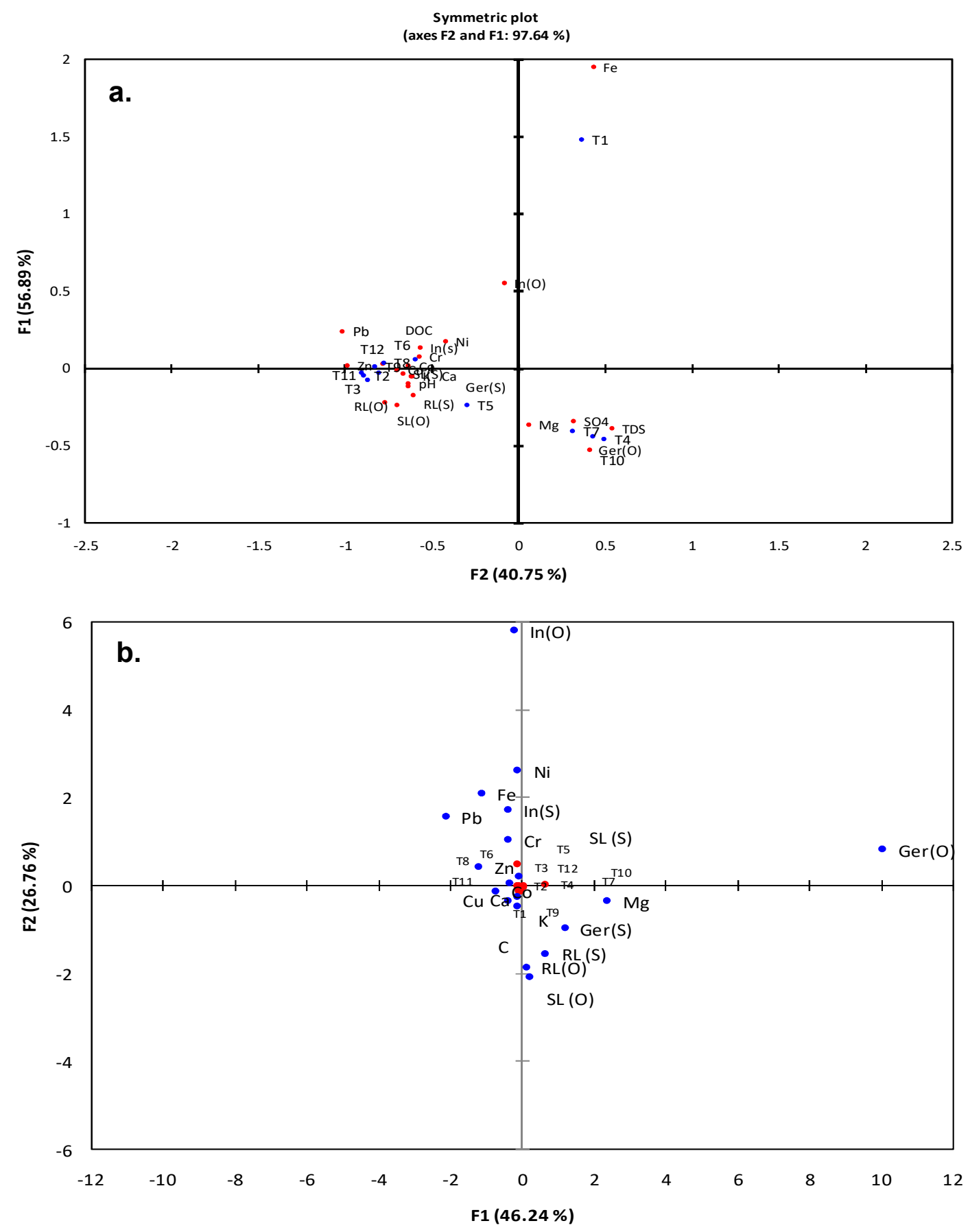

Figure 2: Correspondence analysis of a. lixiviate water quality and germination parameters $b$ metal accumulated in $C$. angustifolia seedlings and germination. [Gen (O) and Gen (S): Germination of O. sanctum and C. angustifolia ; In (O) and $\ln (\mathrm{S})$ : inhibition of $O$. sanctum and $C$. angustifolia; RL and SL: root and shoot length of the respective plant]. 
due to highly acidic $\mathrm{pH}$ and high Fe content. The closeness of $\mathrm{T} 1$ with Fe is corroborating with releasing of the high amount of $\mathrm{Fe}$ at acidic $\mathrm{pH}$. The segregation of T4, T7, and T10 (lixiviate collected at zero hrs from biochar amendments) was due to the high content of $\mathrm{Mg}$, SO42- and TDS contents compared to other biochar treatments. However, lixiviates collected at 15 and 30 days were clustered together besides the difference in the $\mathrm{pH}$ and other components.

Figure (2b) shows the correspondence analysis of metal accumulated in the seedlings and germination parameters of all the treatments. All the treatments ( $T 1$ to $T 12$ ) were clustered together suggests less variability in metal accumulation. However, four groups were formed by other parameters. Inhibition and germination of 0 . sanctum were segregated from the other parameters (Group 1 and Group 2). Inhibition of C. angustifolia was clustered with $\mathrm{Fe}$ and $\mathrm{Ni}$ (group 3), while germination of $\mathrm{C}$. angustifolia and root and shoot length of both plant seedlings were clustered with the Ca, DOC, Ca, K and Mg.

\subsection{Determination of the Contribution of Lixiviate Quality on Germination Using PCA}

PCA analysis was performed separately for each set of treatments to evaluate the impact of lixiviate quality on phytotoxicity. Two groups concerned with lixiviate water composition were formed according to the PCA analysis in each case (Table 5 and Figure 3). This illustrates that two factors can explain the relationship between germination parameters and lixiviate water composition. Variables that have loaded more than 0.6 are only considered to explain each factor.

For mine rejects, a large group of diverse data samples was explained in $61 \%$ and $31 \%$ as the first and second principal components $\left(\mathrm{PC}_{1}\right.$ and $\mathrm{PC}_{2}$ ) (Figure 3a). Two components were extracted, describing approximately $92 \%$ of the common variance. Factor 1 is mostly associated with $\mathrm{pH}, \mathrm{TDS}, \mathrm{DOC}, \mathrm{SO}_{4}{ }^{2-}, \mathrm{Fe}, \mathrm{Co}, \mathrm{Ni}, \mathrm{Zn}, \mathrm{Cr}, \mathrm{Cu}$, and $\mathrm{Pb}$ along with germination, inhibition, and shoot length of both the plant seedlings and root length of 0 . sanctum. It suggests that an increase in $\mathrm{pH}$ improves germination. Factors 2 is associated with the root length of $C$. angustifolia and germination of $\mathrm{O}$. sanctum along with $\mathrm{K}, \mathrm{Mg}, \mathrm{Cr}$, and $\mathrm{Cu}$. The biplot of PC1 and PC2 demonstrates that the concentrations of $\mathrm{pH}, \mathrm{Pb}, \mathrm{Cu}, \mathrm{Ca}$, and $\mathrm{Zn}$ was associated in one group together with the shoot length and root length of $O$. sanctum, which indicates that the leaching behavior of these elements is dependent on $\mathrm{pH}$ and they influence the root and shoot elongation of 0 . sanctum. The correlation data also support this.

On the other hand, $\mathrm{Ni}, \mathrm{DOC}, \mathrm{Co}, \mathrm{Fe}, \mathrm{TDS}$, and $\mathrm{SO}_{4}{ }^{2-}$ were together along with inhibition of both plant seedlings and shoot length of $C$. angustifolia in another cluster and clearly differentiated from the first-mentioned cluster demonstrating relative similar dissolution behavior of $\mathrm{Ni}, \mathrm{Fe}$, and $\mathrm{SO}_{4}{ }^{2-}$. This is plausible because the mobility of $\mathrm{Ni}$, $\mathrm{Co}, \mathrm{Fe}$, and $\mathrm{SO}_{4}{ }^{2-}$ in lixiviate depends upon the formation of stable complexes with organic matter, as discussed previously. They are the major constituents of lixiviate and are responsible for the inhibition of seed germination. $\mathrm{Mg}$ along was clustered with germination of both plant and root length of $\mathrm{C}$. angustifolia. This is reasonable because $\mathrm{Mg}$ is an important element for plant growth and is needed for the synthesis and function of adenosine triphosphate and nucleic acids [50].

InMR+B (Figure $\mathbf{3 b}$ ), factor 1 and factor 2 accounts for $68 \%$ and $29 \%$. Factor 1 is associated with the $\mathrm{pH}$, TDS, $\mathrm{SO}_{4}{ }^{2-}, \mathrm{Fe}, \mathrm{Ca}, \mathrm{K}, \mathrm{Mg}, \mathrm{Co}, \mathrm{Cu}$, and $\mathrm{Pb}$ along with germination and inhibition of both the plant seedlings, shoot, and root length of $C$. angustifolia. While factor 2 comprises the shoot and root length of $O$. sanctum along with $\mathrm{DOC}, \mathrm{Ni}$, $\mathrm{Zn}$, and $\mathrm{Cr}$. The bi-plot showed that the constituents of lixiviate behave differently with different controlling factors and impact on phytotoxicity. $\mathrm{Zn}, \mathrm{Ni}, \mathrm{Cr}, \mathrm{Cu}, \mathrm{Ca}, \mathrm{Mg}, \mathrm{K}, \mathrm{Ca}, \mathrm{SO}_{4}, \mathrm{TDS}$, and $\mathrm{pH}$ as well as root length, inhibition, and germination of both the plants were clustered together, while shoot length of $O$. sanctum was relatively close to this cluster. The $\mathrm{DOC}, \mathrm{Co}$, and $\mathrm{Pb}$ are separated from the first group demonstrating a different dissolution pattern. It demonstrates that the dissolution of the elements present in the first factor is related to the $\mathrm{pH}$, while that in the second factor is controlled by the formation of the complexes with the organic molecules.

For MR-BE (Figure 3c), factor 1 and factor 2 accounts for $60 \%$ and $32 \%$, respectively. Factor 1 is associated with $\mathrm{pH}$, TDS, Fe, Ca, K, Mg, Co, Zn, and $\mathrm{Cr}$ along with inhibition of both plant seedlings, germination of $C$. angustifolia, root length of $C$. angustifolia, and shoot length of $O$. sanctum. Factors 2 are associated with germination and shoot length of Ocimum sanctum and root length of $\mathrm{C}$. angustifolia along with $\mathrm{DOC}, \mathrm{Ni}, \mathrm{Cu}$, and $\mathrm{Pb}$. In bi-plot, the 
association of $\mathrm{pH}, \mathrm{Pb}, \mathrm{Cu}, \mathrm{Fe}$, and $\mathrm{DOC}$ together with germination of $\mathrm{O}$. sanctum and $\mathrm{C}$. angustifolia and shoot length of $C$. angustifolia in one group shows that the release of $\mathrm{Pb}, \mathrm{Cu}$, and $\mathrm{Fe}$ is relatively different for both $\mathrm{MR}-\mathrm{B}_{C}$ and $M R-B_{E}$. This might mean that the properties of biochar seem to have an effect on the dynamics of these elements. It might be possible that an increase in $\mathrm{pH}$ likely increased negative charges on the soil surface, resulting in the higher affinity of the element to the biochar-amended soil surface [51, 52]. Also, they further altered the germination of the seeds. The separation of $\mathrm{Cr}, \mathrm{Ca}, \mathrm{Mg}, \mathrm{Co}, \mathrm{K}, \mathrm{Zn}, \mathrm{Ni}$, and $\mathrm{SO}_{4}{ }^{2-}$ in a different group indicates that similar dissolution processes control their lixiviate mobility.
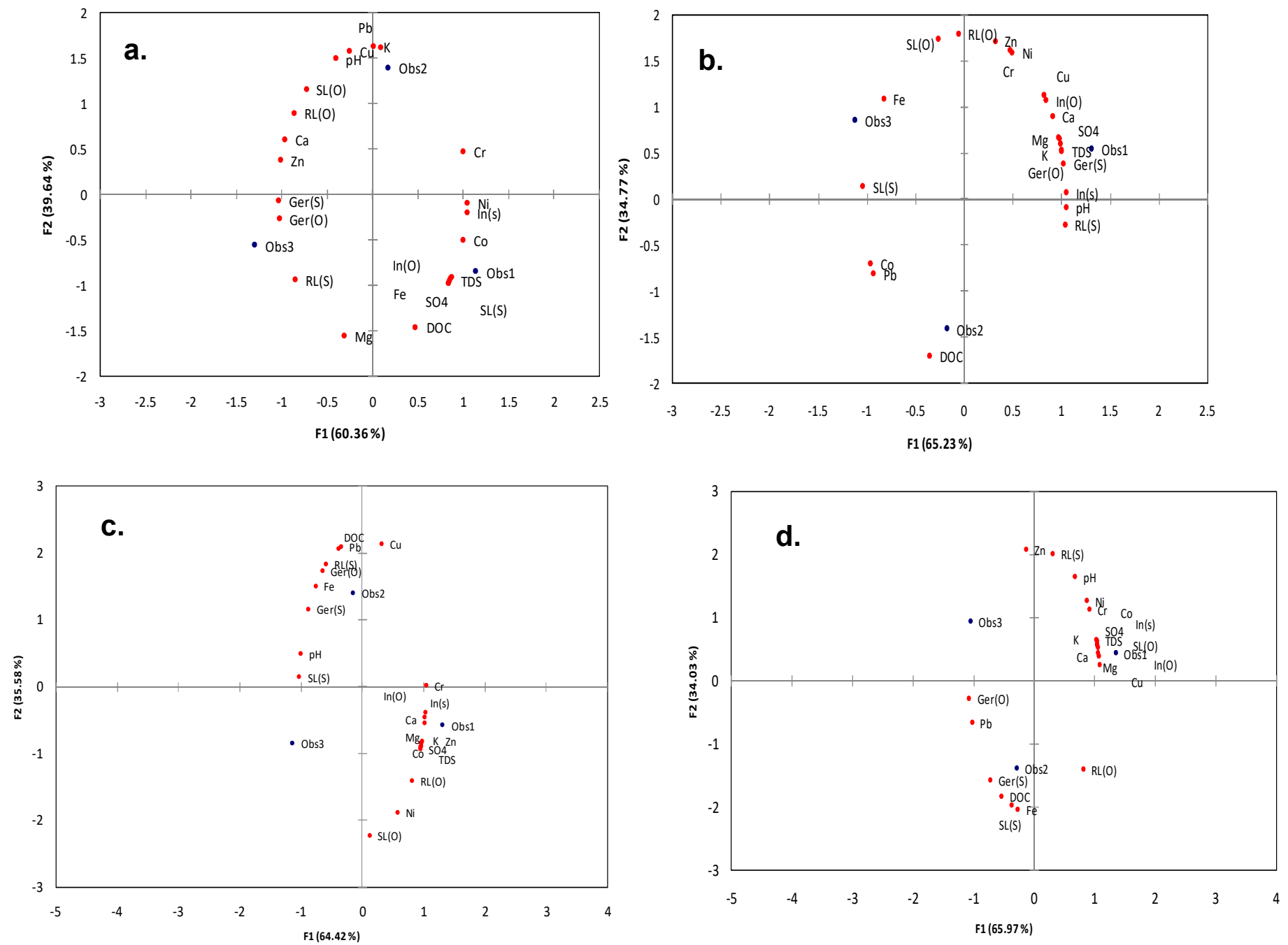

Figure 3: Biplot of PCA analysis of a. mine reject b mine reject with $B L c$. mine reject with $B E d$. mine reject with $B C$. $[G e n(O)$ and Gen (S): Germination of $O$. sanctum and C. angustifolia ; In (O) and In(S): inhibition of O. sanctum and C. angustifolia; RL and SL: root and shoot length of the respective plant].

For $\mathrm{MR}+\mathrm{B}_{\mathrm{C}}$ (Figure $\mathbf{3 d}$ ), factor 1 and factor 2 accounts for $65 \%$ and $30 \%$, respectively. The association pattern on this is quite different. Factor 1 is associated with $\mathrm{TDS}_{1} \mathrm{SO}_{4}{ }^{2-}, \mathrm{Ca}, \mathrm{K}, \mathrm{Mg}, \mathrm{Co}, \mathrm{Ni}, \mathrm{Cr}, \mathrm{Cu}$, and $\mathrm{Pb}$ along with inhibition of plant seedlings, germination, and shoot length of 0 . sanctum. Factors 2 are associated with the shoot and root length of $\mathrm{C}$. angustifolia along with $\mathrm{pH}$ and $\mathrm{DOC}$. In bi-plot, $\mathrm{pH}, \mathrm{Zn}, \mathrm{Ni}, \mathrm{Cr}, \mathrm{Co}, \mathrm{K}, \mathrm{Ca}, \mathrm{Mg}, \mathrm{Cu}$, TDS, and $\mathrm{SO}_{4}{ }^{2-}$ as well as inhibition of both plants and shoot length of $O$. sanctum and root length of $C$. angustifolia were clustered in one group. It demonstrates that $\mathrm{pH}$ is responsible for the dissolution of these elements here. The $\mathrm{DOC}, \mathrm{Pb}$, and Fe are separated from the first group along with germination of both plant and shoot length of $C$. angustifolia, while the shoot length of $O$. sanctum was relatively close to this group. Four groups illustrate that there are significant $(p<0.05)$ differences between all four treatments. The inhibitory effect on the root and shoot elongation depended on a particular lixiviate and plant type component. For example, in $B_{L}$ and $B_{E}$ treatments, root and shoot 
elongation of $\mathrm{O}$. sanctum was linked with $\mathrm{DOC}, \mathrm{Ni}$, and $\mathrm{Zn}$. While, the root and shoot elongation of $\mathrm{C}$. angustifolia in $\mathrm{BC}$ treatments was linked with DOC, Fe, and Zn.

\section{Conclusion}

We concluded that the biochar amendments showed the potential applicability for the remediation and revegetation of the acidic mine-affected areas. The biochar amendments improve the lixiviate quality, germination, and root elongation of $O$. sanctum and $C$. angustifolia. The behavior of each type of biochar was different and governed by the presence of neutralizing elements and dissolved organic content, which altered the distribution of toxic metals between the solid surface phase (adsorption) and the liquid solution. As time progressed, in-situ improvement in the lixiviate quality and phytotoxicity was also observed in mine reject. However, biochar accelerates the process. Also, biochar amendments can provide a solution to the leaching of acid and metal in the groundwater near the mine reject dumping sites.

\section{Acknowledgement}

The authors are thankful to the director of CIMAP for his consistent encouragement.

\section{References}

[1] Baruah B, Khare P. Mobility of trace and potentially harmful elements in the environment from high sulfur Indian coal mines. Applied Geochemistry. 2010; 25(11): 1621-31. https: //doi.org/10.1016/j.apgeochem.2010.08.010

[2] Dutta M, Saikia J, Taffarel SR, Waanders FB, de Medeiros D, Cutruneo CM, et al. Environmental assessment and nano-mineralogical characterization of coal, overburden and sediment from Indian coal mining acid drainage. Geoscience Frontiers. 2017.

[3] Biederman LA, Harpole WS. Biochar and its effects on plant productivity and nutrient cycling: a meta-analysis. GCB bioenergy. 2013; 5(2): 202-14. https: //doi.org/10.1111/gcbb.12037

[4] Beesley L, Inneh OS, Norton G], Moreno-Jimenez E, Pardo T, Clemente R, et al. Assessing the influence of compost and biochar amendments on the mobility and toxicity of metals and arsenic in a naturally contaminated mine soil. Environmental Pollution. 2014; 186: 195-202. https: //doi.org/10.1016/j.envpol.2013.11.026

[5] Lehmann J, Joseph S. Biochar for environmental management: science, technology and implementation: Routledge; 2015.

[6] Al-Wabel MI, Usman ARA, Al-Farraj AS, Ok YS, Abduljabbar A, Al-Faraj Al, et al. Date palm waste biochars alter a soil respiration, microbial biomass carbon, and heavy metal mobility in contaminated mined soil. Environmental Geochemistry and Health. $2017: 1$-18.

[7] Mohamed BA, Ellis N, Kim CS, Bi X, Emam AE-r. Engineered biochar from microwave-assisted catalytic pyrolysis of switchgrass for increasing water-holding capacity and fertility of sandy soil. Science of the Total Environment. 2016; 566: 387-97. https: //doi.org/ 10.1016/j.scitotenv.2016.04.169

[8] Laird D, Fleming P, Wang B, Horton R, Karlen D. Biochar impact on nutrient leaching from a Midwestern agricultural soil. Geoderma. 2010; 158(3): 436-42. https: //doi.org/10.1016/j.geoderma.2010.05.012

[9] Kammann Cl, Linsel S, Gößling JW, Koyro H-W. Influence of biochar on drought tolerance of Chenopodium quinoa Willd and on soilplant relations. Plant and Soil. 2011; 345(1-2): 195-210.

[10] Elmer WH, Pignatello JJ. Effect of biochar amendments on mycorrhizal associations and Fusarium crown and root rot of asparagus in replant soils. Plant Disease. 2011; 95(8): 960-6. https: //doi.org/10.1094/PDIS-10-10-0741

[11] Gartler J, Robinson B, Burton K, Clucas L. Carbonaceous soil amendments to biofortify crop plants with zinc. Science of the Total Environment. 2013; 465: 308-13. https: //doi.org/10.1016/j.scitotenv.2012.10.027

[12] Ippolito J, Berry C, Strawn D, Novak J, Levine J, Harley A. Biochars reduce mine land soil bioavailable metals. Journal of Environmental Quality. 2017; 46(2): 411-9. https: //doi.org/10.2134/jeq2016.10.0388

[13] Tan X, Liu Y, Zeng G, Wang X, Hu X, Gu Y, et al. Application of biochar for the removal of pollutants from aqueous solutions. Chemosphere. 2015; 125: 70-85. https: //doi.org/10.1016/j.chemosphere.2014.12.058

[14] Lu H, Li Z, Fu S, Méndez A, Gascó G, Paz-Ferreiro J. Combining phytoextraction and biochar addition improves soil biochemical properties in a soil contaminated with Cd. Chemosphere. 2015; 119: 209-16. https: //doi.org/10.1016/j.chemosphere.2014.06.024

[15] Sohi S, Krull E, Lopez-Capel E, Bol R. A review of biochar and its use and function in soil. Advances in agronomy. 2010; 105: 47-82. https: //doi.org/10.1016/S0065-2113(10)05002-9

[16] Tan Z, Lin CS, Ji X, Rainey TJ. Returning biochar to fields: A review. Applied Soil Ecology. 2017; 116: 1-11. https: //doi.org/10.1016/j.apsoil. 2017.03.017 
[17] Van Zwieten L, Kimber S, Morris S, Chan K, Downie A, Rust J, et al. Effects of biochar from slow pyrolysis of papermill waste on agronomic performance and soil fertility. Plant and Soil. 2010; 327(1-2): 235-46.

[18] Jain S, Baruah B, Khare P. Kinetic leaching of high sulphur mine rejects amended with biochar: buffering implication. Ecological Engineering. 2014; 71: 703-9. https: //doi.org/10.1016/j.ecoleng.2014.08.003

[19] Ubbelohde AR, Lewis FA. Graphite and its crystal compounds: Clarendon Press; 1960.

[20] Boehm H. Some aspects of the surface chemistry of carbon blacks and other carbons. Carbon. 1994; 32(5): 759-69. https: //doi.org/ 10.1016/0008-6223(94)90031-0

[21] Alexis M, Rasse DP, Rumpel C, Bardoux G, Péchot N, Schmalzer P, et al. Fire impact on C and N losses and charcoal production in a scrub oak ecosystem. Biogeochemistry. 2007; 82(2): 201-16. https: //doi.org/10.1007/s10533-006-9063-1

[22] Kookana RS, Sarmah AK, Van Zwieten L, Krull E, Singh B. 3 biochar application to soil: agronomic and environmental benefits and unintended consequences. Advances in agronomy. 2011; 112(112): 103-43. https: //doi.org/10.1016/B978-0-12-385538-1.00003-2

[23] Courtney R, Mullen G. Use of germination and seedling performance bioassays for assessing revegetation strategies on bauxite residue. Water, air, and soil pollution. 2009; 197(1-4): 15-22.

[24] Czabator FJ. Germination value: an index combining speed and completeness of pine seed germination. Forest Science. 1962; 8(4): 38696.

[25] Hu X, Jiang X, Hwang H, Liu S, Guan H. Promotive effects of alginate-derived oligosaccharide on maize seed germination. Journal of applied phycology. 2004; 16(1): 73-6. https: //doi.org/10.1023/B: JAPH.0000019139.35046.0c

[26] Wang Y, Li L, Cui W, Xu S, Shen W, Wang R. Hydrogen sulfide enhances alfalfa (Medicago sativa) tolerance against salinity during seed germination by nitric oxide pathway. Plant and soil. 2012; 351(1-2): 107-19.

[27] IS B. Methods Of Test For Coal And Coke Ultimate Analysis India: 1959.

[28] Varmuza K, Filzmoser P. Introduction to multivariate statistical analysis in chemometrics: CRC press; 2016.

[29] Zhao L, Cao X, Mašek O, Zimmerman A. Heterogeneity of biochar properties as a function of feedstock sources and production temperatures. Journal of hazardous materials. 2013; 256: 1-9. https: //doi.org/10.1016/j.jhazmat.2013.04.015

[30] Wang $Y, H u ~ Y$, Zhao X, Wang S, Xing G. Comparisons of biochar properties from wood material and crop residues at different temperatures and residence times. Energy \& fuels. 2013; 27(10): 5890-9. https: //doi.org/10.1021/ef400972z

[31] Vassilev SV, Baxter D, Andersen LK, Vassileva CG. An overview of the composition and application of biomass ash. Part 1. Phase-mineral and chemical composition and classification. Fuel. 2013; 105: 40-76. https: //doi.org/10.1016/j.fuel.2012.09.041

[32] Nanda S, Dalai AK, Berruti F, Kozinski JA. Biochar as an exceptional bioresource for energy, agronomy, carbon sequestration, activated carbon and specialty materials. Waste and Biomass Valorization. 2016; 7(2): 201-35. https: //doi.org/10.1007/s12649-015-9459-z

[33] Narzari R, Bordoloi N, Sarma B, Gogoi L, Gogoi N, Borkotoki B, et al. Fabrication of biochars obtained from valorization of biowaste and evaluation of its physicochemical properties. Bioresource Technology. 2017.

[34] Kaudal BB, Chen D, Madhavan DB, Downie A, Weatherley A. An examination of physical and chemical properties of urban biochar for use as growing media substrate. Biomass and Bioenergy. 2016; 84: 49-58. https: //doi.org/10.1016/j.biombioe.2015.11.012

[35] Obia A, Mulder J, Martinsen V, Cornelissen G, Børresen T. In situ effects of biochar on aggregation, water retention and porosity in lighttextured tropical soils. Soil and Tillage Research. 2016; 155: 35-44. https: //doi.org/10.1016/j.still.2015.08.002

[36] Silva LF, Izquierdo M, Querol X, Finkelman RB, Oliveira ML, Wollenschlager M, et al. Leaching of potential hazardous elements of coal cleaning rejects. Environmental monitoring and assessment. 2011; 175(1): 109-26. https: //doi.org/10.1007/s10661-010-1497-1

[37] Martín F, Diez M, García I, Simón M, Dorronsoro C, Iriarte Á, et al. Weathering of primary minerals and mobility of major elements in soils affected by an accidental spill of pyrite tailing. Science of the total environment. 2007; 378(1): 49-52. https: //doi.org/ 10.1016/j.scitotenv.2007.01.031

[38] Park JH, Li X, Edraki M, Baumgartl T, Kirsch B. Geochemical assessments and classification of coal mine spoils for better understanding of potential salinity issues at closure. Environmental Science: Processes \& Impacts. 2013; 15(6): 1235-44. https: //doi.org/ 10.1039/c3em30672k

[39] de Vallejuelo SF-O, Gredilla A, da Boit K, Teixeira EC, Sampaio CH, Madariaga JM, et al. Nanominerals and potentially hazardous elements from coal cleaning rejects of abandoned mines: Environmental impact and risk assessment. Chemosphere. 2017; 169: 72533. https: //doi.org/10.1016/j.chemosphere.2016.09.125

[40] Zornoza R, Gómez-Garrido M, Martínez-Martínez S, Gómez-López MD, Faz Á. Bioaugmentaton in Technosols created in abandoned pyritic tailings can contribute to enhance soil C sequestration and plant colonization. Science of the total environment. 2017; 593: 35767. https: //doi.org/10.1016/j.scitotenv.2017.03.154

[41] Mosley LM, Daly R, Palmer D, Yeates P, Dallimore C, Biswas T, et al. Predictive modelling of pH and dissolved metal concentrations and speciation following mixing of acid drainage with river water. Applied Geochemistry. 2015; 59: 1-10. https: //doi.org/10.1016/ j.apgeochem.2015.03.006

[42] González V, García I, Del Moral F, Simón M. Effectiveness of amendments on the spread and phytotoxicity of contaminants in metalarsenic polluted soil. Journal of hazardous materials. 2012; 205: 72-80. https: //doi.org/10.1016/j.jhazmat.2011.12.011 
[43] Subedi R, Taupe N, Pelissetti S, Petruzzelli L, Bertora C, Leahy J, et al. Greenhouse gas emissions and soil properties following amendment with manure-derived biochars: Influence of pyrolysis temperature and feedstock type. Journal of environmental management. 2016; 166: 73-83. https: //doi.org/10.1016/j.jenvman.2015.10.007

[44] Beesley L, Dickinson N. Carbon and trace element mobility in an urban soil amended with green waste compost. Journal of Soils and Sediments. 2010; 10(2): 215-22. https: //doi.org/10.1007/s11368-009-0112-y

[45] Igalavithana AD, Park J, Ryu C, Lee YH, Hashimoto Y, Huang L, et al. Slow pyrolyzed biochars from crop residues for soil metal (loid) immobilization and microbial community abundance in contaminated agricultural soils. Chemosphere. 2017; 177: 157-66. https: //doi.org/10.1016/j.chemosphere.2017.02.112

[46] Singh B, Sherman D, Gilkes R, Wells M, Mosselmans J. Structural chemistry of Fe, Mn, and Ni in synthetic hematites as determined by extended X-ray absorption fine structure spectroscopy. Clays and Clay Minerals. 2000; 48(5): 521-7. https: //doi.org/10.1346/ CCMN.2000.0480504

[47] Bae J, Benoit DL, Watson AK. Effect of heavy metals on seed germination and seedling growth of common ragweed and roadside ground cover legumes. Environmental Pollution. 2016; 213: 112-8. https: //doi.org/10.1016/j.envpol.2015.11.041

[48] Sun J, Drosos M, Mazzei P, Savy D, Todisco D, Vinci G, et al. The molecular properties of biochar carbon released in dilute acidic solution and its effects on maize seed germination. Science of The Total Environment. 2017; 576: 858-67.https: //doi.org/10.1016/ j.scitotenv.2016.10.095

[49] Pardo T, Martínez-Fernández D, Clemente R, Walker DJ, Bernal MP. The use of olive-mill waste compost to promote the plant vegetation cover in a trace-element-contaminated soil. Environmental Science and Pollution Research. 2014; 21(2): 1029-38. https: //doi.org/ $10.1007 / \mathrm{s} 11356-013-1988-z$

[50] Ceylan Y, Kutman UB, Mengutay M, Cakmak I. Magnesium applications to growth medium and foliage affect the starch distribution, increase the grain size and improve the seed germination in wheat. Plant and Soil. 2016; 406(1-2): 145-56.

[51] Bakshi S, He ZL, Harris WG. Biochar amendment affects leaching potential of copper and nutrient release behavior in contaminated sandy soils. Journal of environmental quality. 2014; 43(6): 1894-902. https: //doi.org/10.2134/jeq2014.05.0213

[52] Ahmad M, Rajapaksha AU, Lim JE, Zhang M, Bolan N, Mohan D, et al. Biochar as a sorbent for contaminant management in soil and water: a review. Chemosphere. 2014; 99: 19-33. https: //doi.org/10.1016/j.chemosphere.2013.10.071 